\title{
Safety of standardised treatments for haematologic malignancies as regards to testicular endocrine function in children and teenagers
}

\author{
Romina P. Grinspon', María Arozarena², Silvina Prada², \\ Graciela Bargman ${ }^{3}$, María Sanzone', Marjorie Morales Bazurto', \\ Marcela Gutiérrez ${ }^{2}$, Patricia Bedecarrás', Ana Kannemann ${ }^{4}$, \\ Graciela O. Elena ${ }^{4}$, Silvia Gottlieb', Ariel J. Berenstein ${ }^{5}$, \\ María Gabriela Ropelato', Ignacio Bergadá', Luis A. Aversa² ${ }^{2}$ and \\ Rodolfo A. Rey ${ }^{1, *}$
}

\begin{abstract}
'Centro de Investigaciones Endocrinológicas “Dr. César Bergadá” (CEDIE), CONICET-FEI-División de Endocrinología, Hospital de Niños Ricardo Gutiérrez, CI425EFD Buenos Aires, Argentina ${ }^{2}$ Unidad de Hematología, Hospital de Niños Ricardo Gutiérrez, CI 425EFD Buenos Aires, Argentina ${ }^{3}$ División de Endocrinología, Hospital de Niños Pedro de Elizalde, CI270AAN Buenos Aires, Argentina ${ }^{4}$ Unidad de Hematología, Hospital Pedro de Elizalde, CI 270AAN Buenos Aires, Argentina ${ }^{5}$ Instituto Multidisciplinario de Investigaciones en Patologías Pediátricas (IMIPP), CONICET-GCBA, Laboratorio de Biología Molecular, División Patología, Hospital de Niños Ricardo Gutiérrez, Cl425EFD Buenos Aires, Argentina.
\end{abstract}

*Correspondence address. Centro de Investigaciones Endocrinológicas “Dr. César Bergadá” (CEDIE), CONICET-FEI-División de Endocrinología, Hospital de Niños Ricardo Gutiérrez, Gallo 1330, CI425EFD Buenos Aires, Argentina. E-mail: rodolforey@cedie.org.ar

Submitted on June 3, 2019; resubmitted on September 2, 2019; editorial decision on September 6, 2019

STUDY QUESTION: Does standardised treatments used in children and adolescents with haematologic malignancies, including acute lymphoblastic (ALL) or myeloid leukaemia (AML) and non-Hodgkin lymphoma (NHL), affect endocrine function of the developing testes?

SUMMARY ANSWER: Therapy of haematologic malignancies do not provoke an overt damage of Sertoli and Leydig cell populations, as revealed by normal levels of anti-Müllerian hormone $(\mathrm{AMH})$ and testosterone, but a mild primary testicular dysfunction may be observed, compensated by moderate gonadotropin elevation, during pubertal development.

WHAT IS KNOWN ALREADY: Evidence exists on the deleterious effect that chemotherapy and radiotherapy have on germ cells, and some attention has been given to the effects on Leydig and Sertoli cells of the adult gonads, but information is virtually non-existent on the effects of oncologic treatment on testicular somatic cell components during childhood and adolescence.

STUDY DESIGN, SIZE, DURATION: A retrospective, analytical, observational study included 97 boys with haematological malignancies followed at two tertiary paediatric public hospitals in Buenos Aires, Argentina, between 2002 and 2015.

PARTICIPANTS/MATERIALS, SETTING, METHODS: Clinical records of males aged I-I8 years, referred with the diagnoses of ALL, AML or NHL for the assessment of gonadal function, were eligible. We assessed serum levels of AMH and FSH as biomarkers of Sertoli cell endocrine function and testosterone and $\mathrm{LH}$ as biomarkers of Leydig cell function.

MAIN RESULTS AND THE ROLE OF CHANCE: All hormone levels were normal in the large majority of patients until early pubertal development. From Tanner stage G3 onwards, while serum AMH and testosterone kept within the normal ranges, gonadotropins reached mildly to moderately elevated values in up to $35.9 \%$ of the cases, indicating a compensated Sertoli and/or Leydig cell dysfunction, which generally did not require hormone replacement therapy.

LIMITATIONS, REASONS FOR CAUTION: Serum inhibin B determination and semen analysis were not available for most patients; therefore, we could not conclude on potential fertility impairment or identify whether primary Sertoli cell dysfunction resulted in secondary depleted spermatogenesis or whether primary germ cell damage impacted Sertoli cell function.

WIDER IMPLICATIONS OF THE FINDINGS: The regimens used in the treatment of boys and adolescents with ALL, AML or NHL in the past two decades seem relatively safe for endocrine testicular function; nonetheless, a mild primary testicular endocrine dysfunction 
may be observed, usually compensated by slightly elevated gonadotropin secretion by the pituitary in adolescents, and not requiring hormone replacement therapy. No clinically relevant risk factor, such as severity of the disease or treatment protocol, could be identified in association with the compensated endocrine dysfunction.

STUDY FUNDING/COMPETING INTEREST(S): This work was partially funded by grants PIP I I 220 I30 I 00687 of Consejo Nacional de Investigaciones Científicas y Técnicas (CONICET) and PICT 2016-0993 of Fondo para la Investigación Científica y Tecnológica (FONCYT), Argentina. R.A.R., R.P.G. and P.B. have received honoraria from CONICET (Argentina) for technology services using the AMH ELISA. L.A.A. is part-time employee of CSL Behring Argentina. The other authors have no conflicts of interest to disclose.

Key words: anti-Müllerian hormone / chemotherapy / gonadotropins / hypogonadism / leukaemia / lymphoma / Sertoli cells / testosterone

\section{Introduction}

Haematologic malignancies account for almost $40 \%$ of paediatric cancers (Armstrong et al., 20l6), with an annual incidence of $\sim 30$ cases per million children and adolescents $<20$ years of age (Hunger and Mullighan, 2015). Acute lymphoblastic leukaemia (ALL), the most prevalent paediatric malignancy, occurs more frequently in children of Latin/Hispanic ancestries compared with other ancestries in the United States (Lim et al., 20I4), with a slight predominance in males (Hunger and Mullighan, 20I5).

The use of effective chemotherapy and radiotherapy for the management of childhood cancer has resulted in remarkable improvements in overall survival over the past decades. The 5-year survival rate for ALL, acute myeloid leukaemia (AML) and non-Hodgkin lymphoma (NHL) has increased to $\sim 90 \%$ following the development of intensive multi-drug, induction and consolidation regimens including intrathecal chemotherapy (Hunger and Mullighan, 20I5). This marked improvement in therapy has led to a growing population of childhood cancer survivors, who are subject to long-term sequelae impacting on health issues, the most frequent being endocrine disorders (Crowne et al., 20I5). In particular, cancer treatment can affect reproductive function, and loss of fertility has become an important concern.

The adult testis produces spermatozoa and hormones. Spermatozoa arise from germ cells within the seminiferous tubules, whereas hormones are secreted by specific somatic cell populations: androgens by Leydig cells present in the interstitial tissue and inhibin B by Sertoli cells located within the seminiferous tubules, where they also give functional support to germ cells. In the prepubertal gonad, the germ cell population is represented exclusively by pre-meiotic spermatogonia that self-renew by mitosis, while immature Sertoli cells produce antiMüllerian hormone $(\mathrm{AMH})$ and inhibin $\mathrm{B}$, and mature Leydig cells are absent owing to the lack of LH stimulation (Rey, 20l4, Stukenborg et al., 2018).

A large amount of evidence exists on the deleterious effect that chemotherapy agents and irradiation reaching the testes have on germ cells that have a high mitotic rate (reviewed by Jahnukainen and Stukenborg, 2012, Gebauer et al., 2018 and Kesari et al., 20।8). Some attention has been focused on the effects of chemotherapy and radiotherapy on the Leydig (Brämswig et al., 1990, Heikens et al., 1996, Kenney et al., 2012) and Sertoli (Heikens et al., 1996, Bar-Shira Maymon et al., 2004, Bordallo et al., 2004, van Beek et al., 2007, Lahteenmaki et al., 2008, Cuny et al., 20 II, Laporte et al., 20II) cell populations of the adult gonads and to late effects observed during adulthood in patients having received oncologic treatments during childhood. Leydig and Sertoli cell failure seems relatively rare after chemotherapy in the adult and involves a significantly higher irradiation dose than that required to cause germ cell damage. Conversely, information is virtually non-existent on the effects of cancer treatment on the somatic cell components of the prepubertal testis (reviewed by Stukenborg et al., 2018 and Allen et al., 20I8).

Recent research on the effects of cancer treatment has focused on preventing damage. However, this is challenging for prepubertal males for whom fertility preservation is not possible given that they do not produce spermatozoa that can be cryopreserved. Some centres have started to cryopreserve spermatogonial stem cells, which could be transplanted back into the testes later in life and give rise to sperm (Stukenborg et al., 20 I8). Nonetheless, normal function of the Sertoli and Leydig cells exposed to cancer treatment would be essential for the success of this therapeutic approach. Furthermore, endocrine testicular function is important for pubertal development, especially for the achievement of a normal growth spurt and bone mass accrual (Sklar et al., 20l8).

In this work, we aimed to determine whether the oncologic treatments used in prepubertal and pubertal boys with ALL, AML or NHL, the set of most frequent paediatric cancers, affect the endocrine function of the somatic component of the developing testis. In an observational study on a large cohort of patients treated before or after the age of 10 years, with long-term follow-up, we assessed serum levels of AMH and FSH as direct and indirect biomarkers respectively of Sertoli cell function, and testosterone and $\mathrm{LH}$ as direct and indirect biomarkers respectively of Leydig cell function.

\section{Materials and methods}

\section{Study design and setting}

We performed a retrospective, analytical, observational study at Ricardo Gutiérrez and Pedro de Elizalde Children's Hospitals, two tertiary paediatric public hospitals in Buenos Aires, Argentina. Clinical and laboratory data were extracted from the clinical charts.

The diagnoses of haematologic malignancies were made according to the third and fourth editions of the World Health Organisation Classification of Tumours of Haematopoietic and Lymphoid Tissues (Arber et al., 20I6). For patients with ALL, risk stratification and treatment were assigned according to the ALL IC-BFM 2002 intercontinental trial (Stary et al., 20I4). Briefly, three risk groups were defined: standard risk (SR), intermediate risk (IR) and high risk (HR), as described in Supplementary Fig. SI. 


\section{Patients}

\section{Inclusion criteria}

All clinical records of males aged $I-18$ years, referred with the diagnoses of ALL, AML or NHL from the Units of Haematology to the Divisions of Endocrinology of Ricardo Gutiérrez and Pedro de Elizalde Children's Hospital for the assessment of gonadal function between 2002 and 2015, were eligible.

\section{Exclusion criteria}

Clinical records were excluded from the analysis when the malignancy involved the central nervous system or the testes, in cases of trisomy 2I (Grinspon et al., 20I I) or in any other condition known to affect the hypothalamic-pituitary-testicular axis (Rey et al., 2013), in order to avoid potential confusion due to known causes of central or primary hypogonadism.

\section{Outcome measures and definitions}

Two different analyses were performed. For the cross-sectional analysis, clinical records were included for patients with at least I year of follow-up after the end of chemotherapy and one endocrine assessment of testicular function (including serum levels of $\mathrm{AMH}$, testosterone, FSH and $\mathrm{LH}$ ) between $\mathrm{I}$ and 8 years after the end of chemotherapy. For the longitudinal study, all clinical records were included. For the analyses of serum hormones, patients were grouped according to pubertal stages as defined by Marshall and Tanner (1970). Owing to the retrospective design of the study, testicular volume, genital development and pubic hair staging were obtained from the history charts as reported by the patient's paediatric endocrinologist. Testicular volume was obtained by comparison with Prader's orchidometer, with the inter-individual variability inherent to the assessment method.

The main outcome measures of the study were the serum concentrations of $\mathrm{AMH}$, testosterone, $\mathrm{FSH}$ and $\mathrm{LH}$. Values were expressed in absolute levels and as standard deviation scores (SDS) based on age- and Tanner genital stage-matched reference ranges (see Supplementary Table SI), previously published by our laboratory (Grinspon et al., 20II, Grinspon et al., 2012b). Values of AMH and testosterone below -2 SDS were considered direct markers of affected testicular function. Values of FSH and $\mathrm{LH}$ above +2 SDS were considered indirect markers of affected testicular function. The use of SDS allowed the analysis of the whole cohort, whereas the use of absolute levels required a subgroup analysis by age and Tanner genital stage.

For the primary analysis, exposure measures, i.e. chemotherapy and radiotherapy, were analysed together and separately. Due to the retrospective design of our study, we did not have clinical Tanner staging data at the end of treatment, since patients were referred for endocrine assessment after the end of oncologic treatment. We intended to assess separately the effect of cancer treatment on boys who received the whole treatment at a prepubertal period, i.e. when the hypothalamic-pituitary-testicular axis is mainly quiescent (low mitotic index for all cell types), and on boys who were more likely exposed to a reactivated axis (characterised by a higher mitotic index in testicular cells). The classical clinical signs of pubertal onset, i.e. testicular volume and Tanner stages, were not used for categorising patients at the time of the end of treatment because cancer treatment could affect

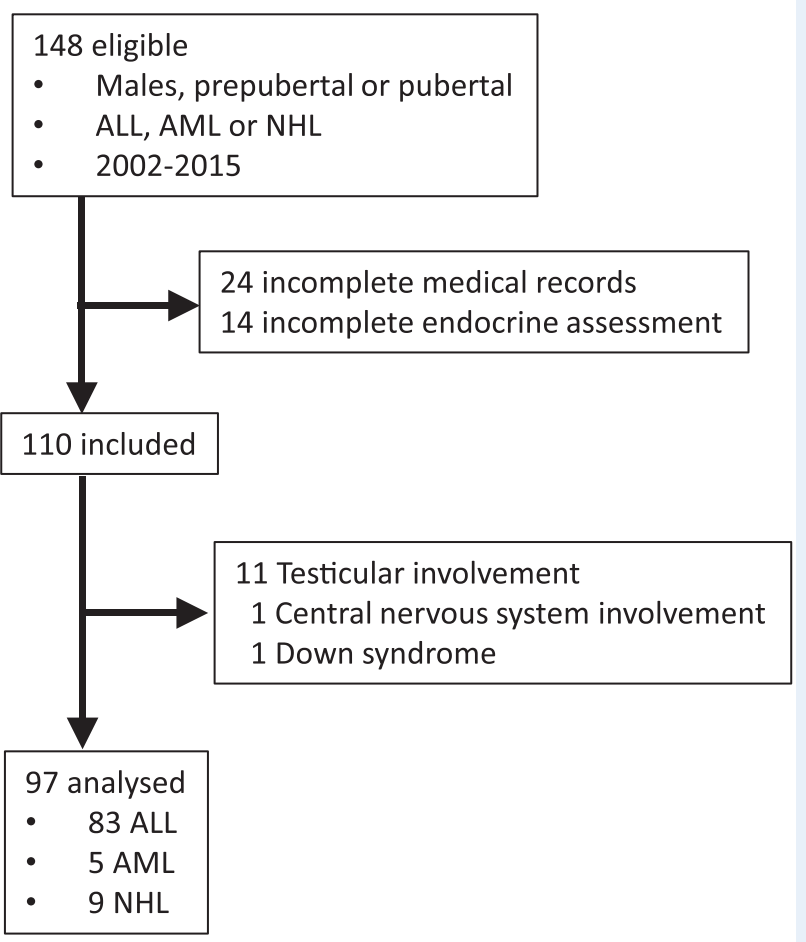

Figure I Flow chart of patient inclusion in the study.

testicular size and pubertal development (Crowne et al., 20I5). Like other authors (Romerius et al., 20 I I), we chose to use an age cut-off of 10 years based on population studies indicating that in boys $<10$ years of age the likelihood of having started pubertal development is $<5 \%$ (Tomova et al., 2010) and the classical Tanner study indicating that at 9.5 years $<2.5 \%$ of boys have reached G2 (Marshall and Tanner, 1970). Therefore, two subgroups were considered, according to the age at which chemotherapy or radiotherapy ended: $<10$ years old (Group A) and $\geq 10$ years old (Group B).

\section{Hormone assays}

Hormonal values were extracted from the clinical charts and the laboratory Cobas ${ }^{\circledR}$ Infinity system (Roche). The AMH assay for all samples (Ricardo Gutiérrez and Pedro de Elizalde Children's Hospitals) was centralised in the Ricardo Gutiérrez laboratory. Gonadotropin and testosterone measurements were performed in both hospitals, using the same methods.

\section{$\mathrm{AMH}$}

Serum AMH was determined using an enzyme-linked immunoassay specific for human AMH (EIA AMH/MIS ${ }^{\circledR}$, Beckman-Coulter Co., Marseilles, France), as previously validated by our group (Grinspon et al., 20 I I, Grinspon et al., 20 I2b). Intra- and inter-assay coefficients of variation were, respectively, $10.5 \%$ and $9.4 \%$ for a serum $\mathrm{AMH}$ concentration of $700 \mathrm{pmol} / \mathrm{I}$, and $1 \mathrm{I} .1 \%$ and $12.8 \%$ for a serum $\mathrm{AMH}$ concentration of $7 \mathrm{pmol} / \mathrm{I}$. When serum $\mathrm{AMH}$ levels were undetectable, a value of I pmol/I, corresponding to the limit of quantification (functional sensitivity), was attributed. 
Table I Characteristics of the whole study sample.

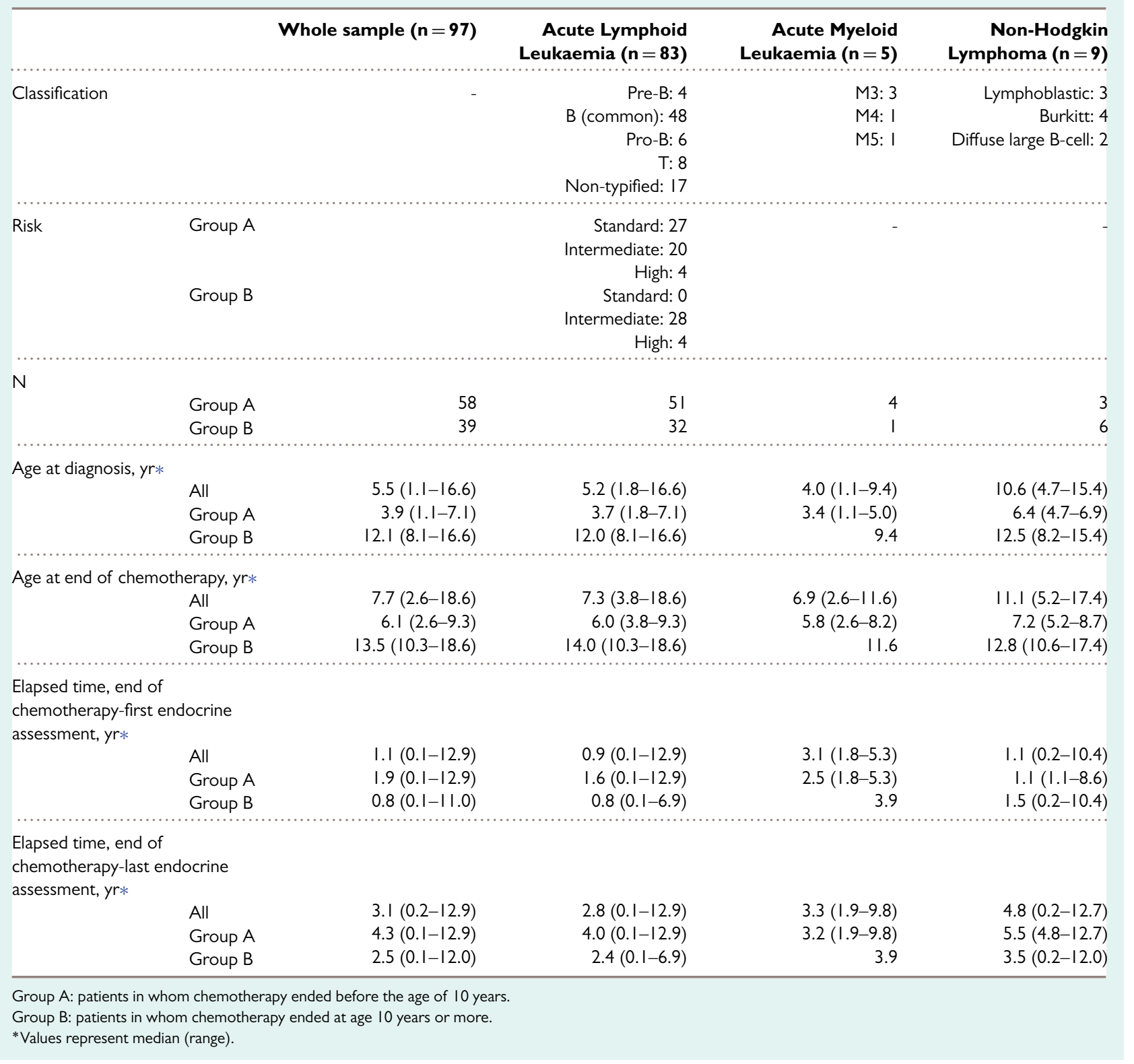

\section{Gonadotropins}

$\mathrm{LH}$ and FSH were determined using electro-chemiluminescent immunoassays (ECLIA, Roche Diagnostics GmbH, Mannheim, Germany) as described (Grinspon et al., 20/2b). The limits of quantification of both $\mathrm{LH}$ and FSH assays were $0.10 \mathrm{IU} / \mathrm{I}$, according to the 2nd National Institute for Biological Standards and Control International Standard 80/552 for $\mathrm{LH}$ and the 2nd World Health Organisation International Reference Preparation 78/549 for FSH. Intra- and inter-assay coefficients of variation were $1.1 \%$ and $1.8 \%$ for $\mathrm{LH}$, respectively, for a mean $\mathrm{LH}$ concentration of $2.8 \mathrm{IU} / \mathrm{I}$ and $\mathrm{I} .4 \%$ and I.5\% for a mean LH concentration of $16.9 \mathrm{IU} / \mathrm{I}$. Intra- and inter-assay coefficients of variation were $1.0 \%$ and $4.2 \%$ for $\mathrm{FSH}$, respectively, for a mean FSH concentration of $14.8 \mathrm{IU} / \mathrm{I}$ and $\mathrm{I} . \mathrm{I} \%$ and $4.1 \%$ for a mean FSH concentration of $23.4 \mathrm{IU} / \mathrm{I}$. When serum $\mathrm{LH}$ or FSH levels were undetectable, the value of the limit of quantification (functional sensitivity) was attributed.

\section{Testosterone}

Testosterone was determined in serum using an electrochemiluminescent immunoassay (ECLIA, Roche Diagnostics GmbH, Mannheim, Germany) as described (Grinspon et al., 20I I). Intra- and inter-assay coefficients of variation were $2.4 \%$ and $2.6 \%$, respectively, for a mean testosterone concentration of $176 \mathrm{ng} / \mathrm{dl}(6.10 \mathrm{nmol} / \mathrm{l})$ and I. $2 \%$ and $2.3 \%$ for a mean testosterone concentration of $455 \mathrm{ng} / \mathrm{dl}$ (I5.78 nmol/I). When serum testosterone levels were undetectable, a value of $10 \mathrm{ng} / \mathrm{dl}(0.347 \mathrm{nmol} / \mathrm{l})$, corresponding to the limit of quantification (functional sensitivity), was attributed.

\section{Statistical analyses}

Data distribution was assessed for normality using the Shapiro-Wilk test. Results are expressed as median and range. Because non-Gaussian distribution was found in most cases, nonparametric tests were used 
Table II Characteristics of the study sample included in the cross-sectional analysis.

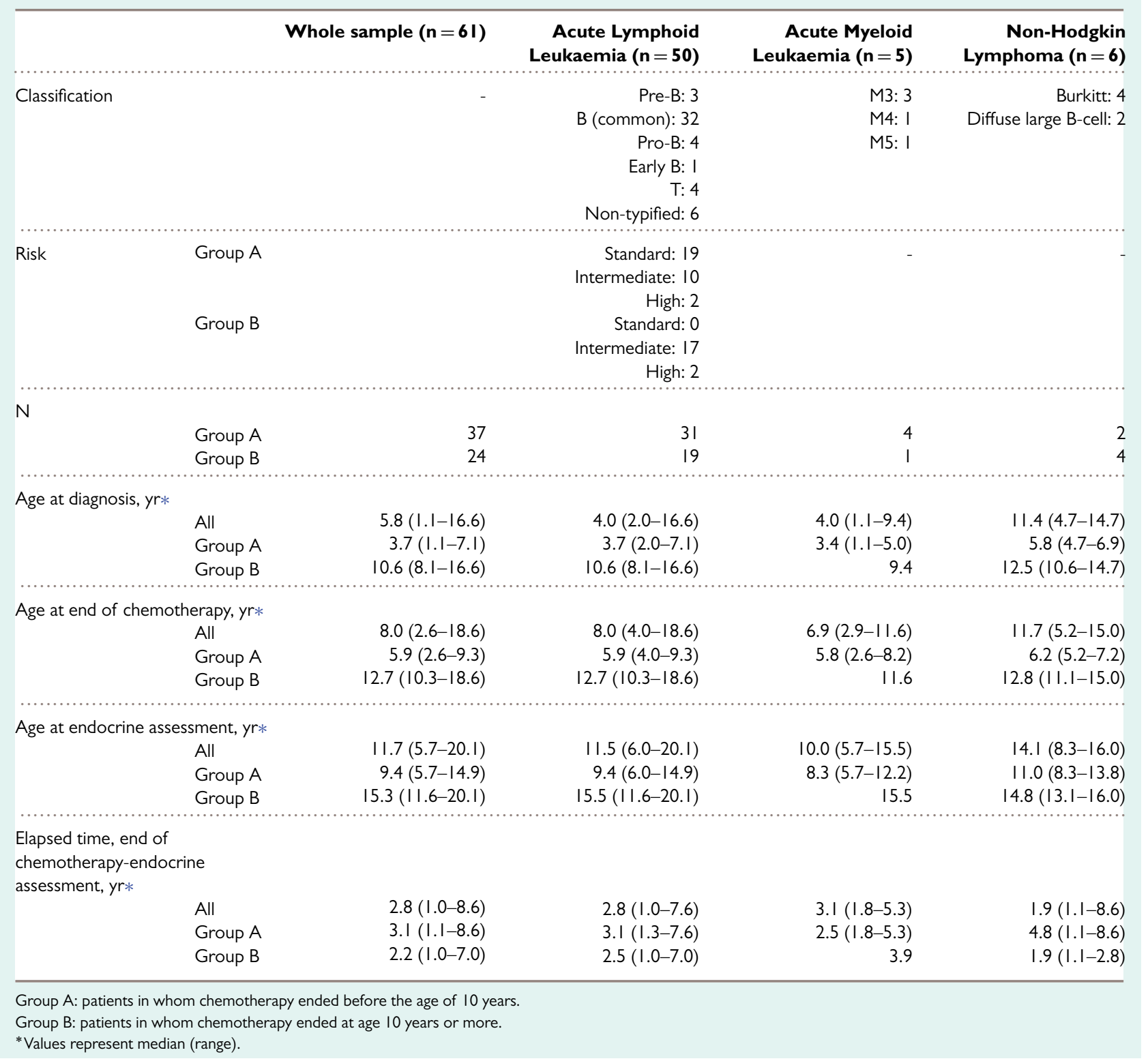

for comparisons. Fisher's exact test was used to compare categorical variables. To assess the existence of association between chemotherapy agent cumulative doses and gonadal dysfunction, a logistic regression model was used, considering cumulative doses as continuous variables and gonadal dysfunction as dichotomised (FSH or $\mathrm{LH}>+2$ SDS considered as gonadal dysfunction; $\leq+2$ SDS considered as normal). Odds ratios and $95 \%$ confidence intervals for the final model were reported. The level of significance was set at $P<0.05$. All statistical analyses were performed using GraphPad Prism version 8.02 for Windows (GraphPad Software, San Diego, CA, USA) and STATA I3 (StataCorp LLC, College Station, TX, USA).

\section{Ethical issues}

Research was conducted in accordance with principles of the Declaration of Helsinki. The study protocol was approved by the Institutional Review Boards of the Ricardo Gutiérrez and Pedro de Elizalde
Children's Hospitals, Buenos Aires. Because the study was based on a retrospective clinical chart review with descriptive purposes and no anticipated effect on prognosis or therapeutic management of the patients whose charts were included, the need for a written informed consent was waived.

\section{Results}

\section{Characteristics of the study sample}

Our database contained 148 eligible males with a diagnosis of ALL, AML or NHL, endocrinologically assessed between 2002 and 2015 (Fig. I). Due to incomplete medical records or endocrine assessment, 38 could not be included and 13 patients were excluded because they were highly likely to have hypothalamic-pituitary-testicular involvement prior to the initiation of treatment for ALL, AML or NHL: I I with testicular and I with central nervous system involvement of 


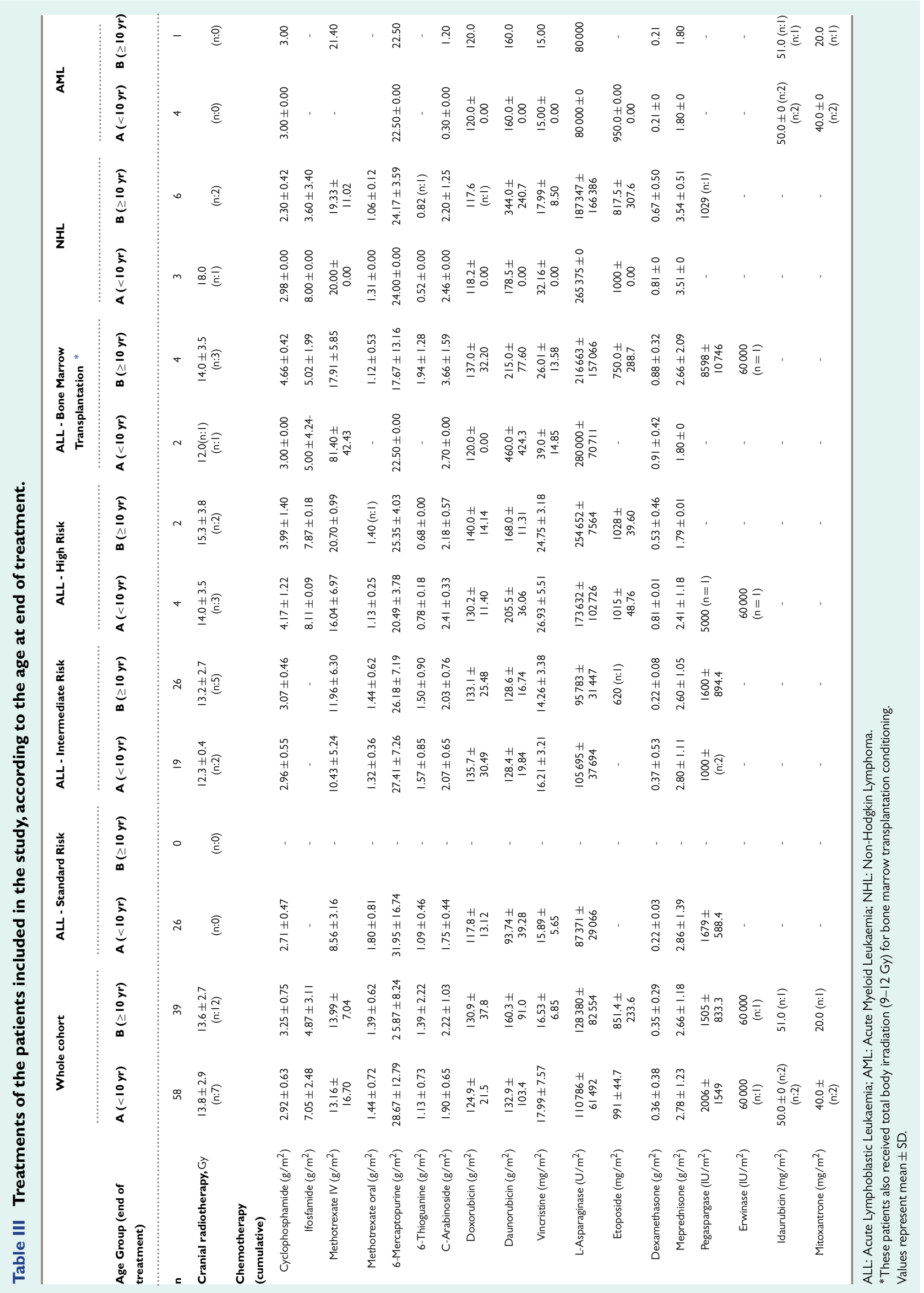


A

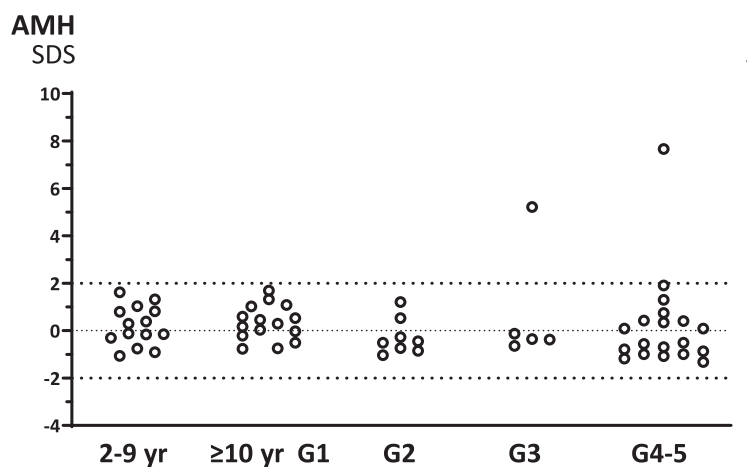

SDS
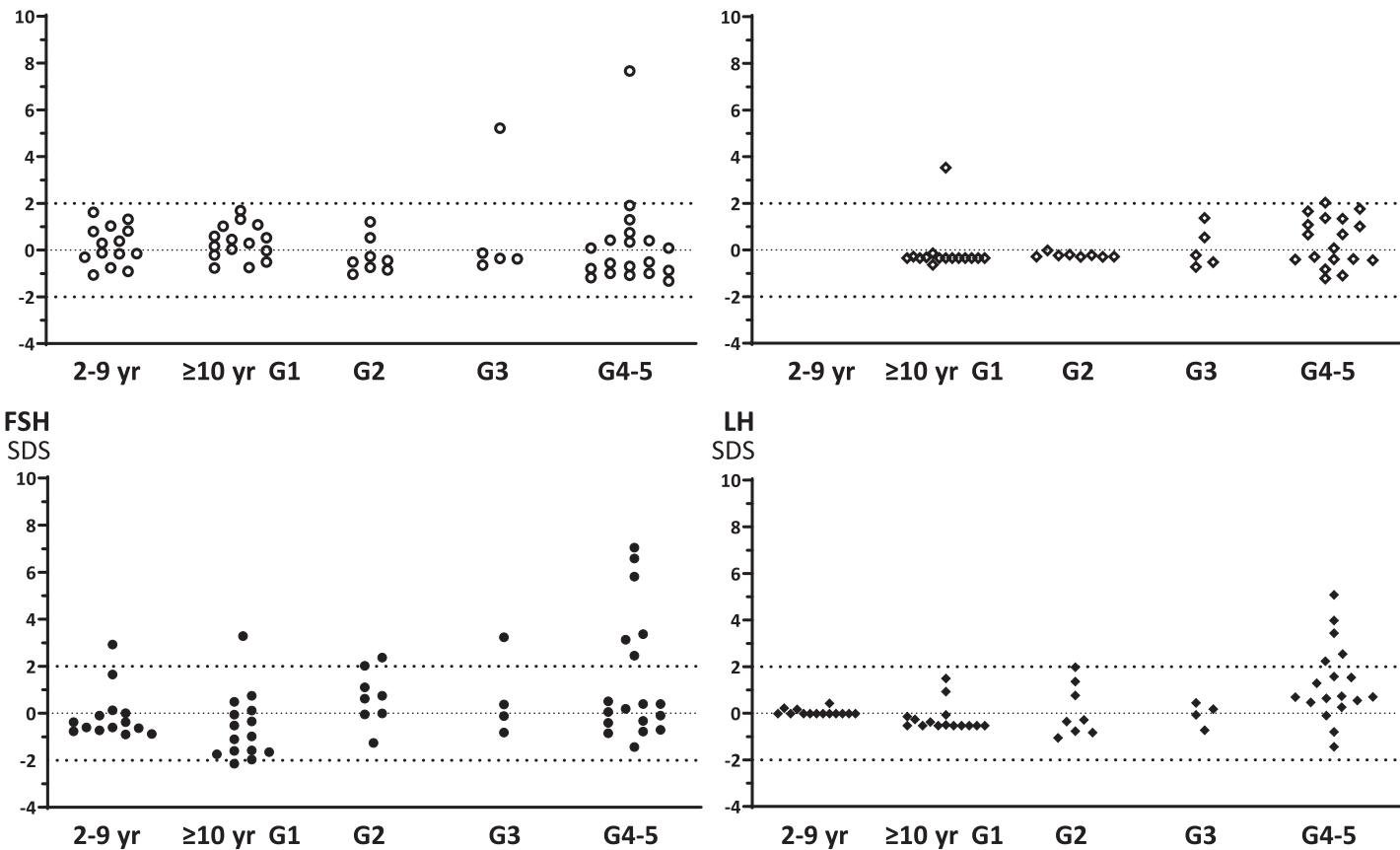

LH

${ }^{10} 7$.

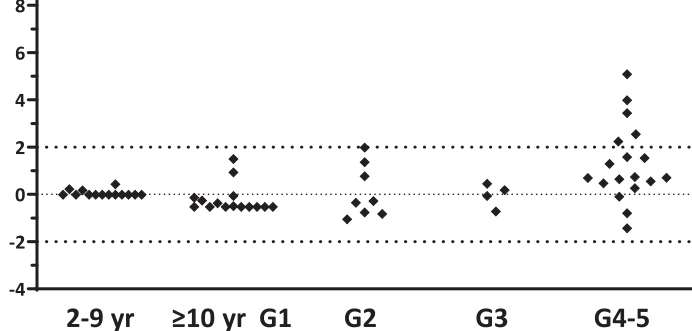

B
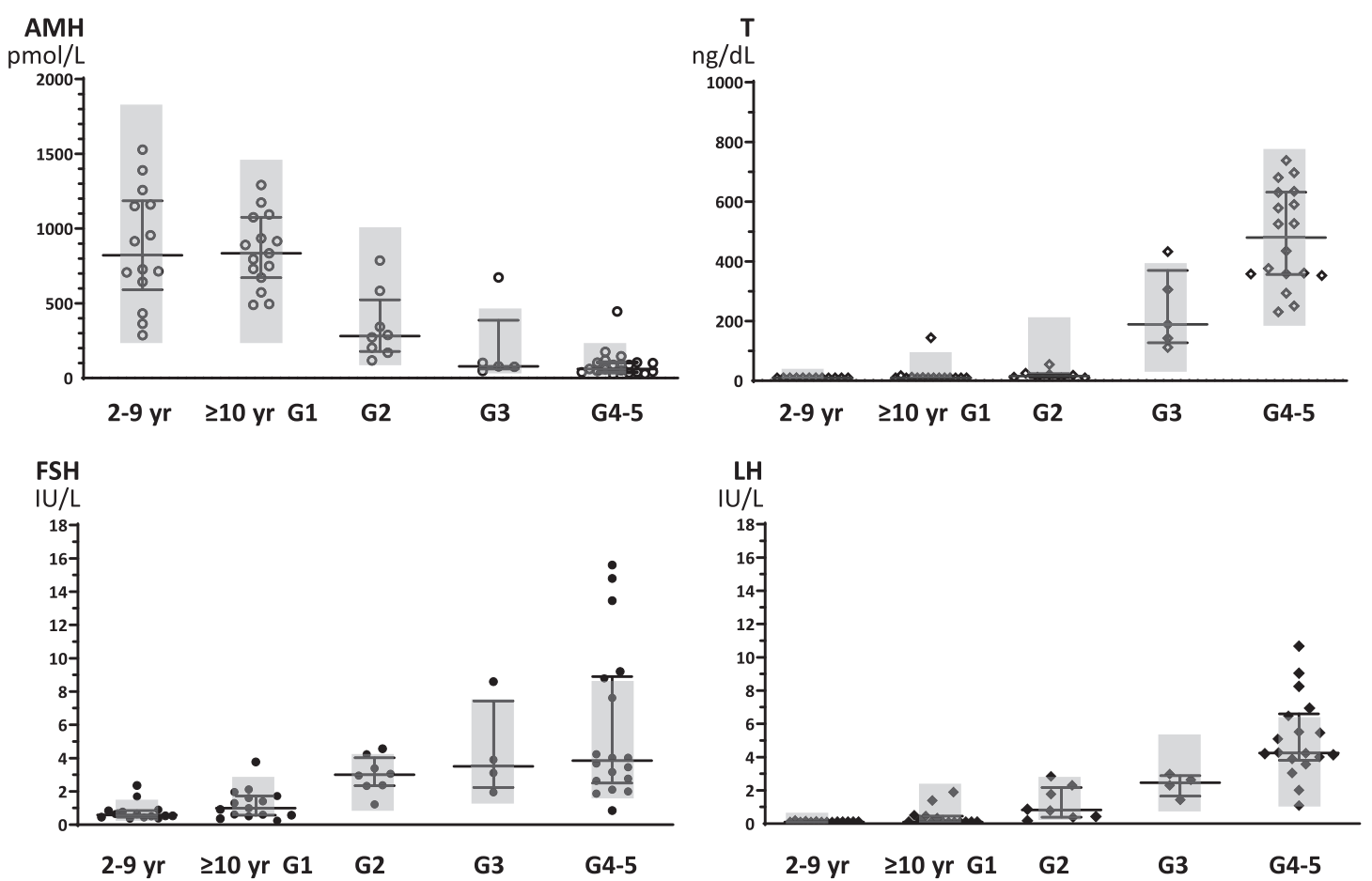

Figure 2 Serum levels of AMH, testosterone and gonadotropins in the 61 boys with ALL, AML or NHL included in the crosssectional study. Patients are grouped according to age or pubertal Tanner stage at the moment of hormone determination. One value per patient obtained no earlier than I year after the end of chemotherapy. (A) Values expressed as SDS for age and Tanner genital stage. (B) Absolute values; the grey areas represent normal reference levels for age and Tanner genital stage. Both A and B are according to Grinspon et al., 20I I. ALL: acute lymphoblastic leukaemia; AML: acute myeloid leukaemia; NHL: non-Hodgkin lymphoma. 


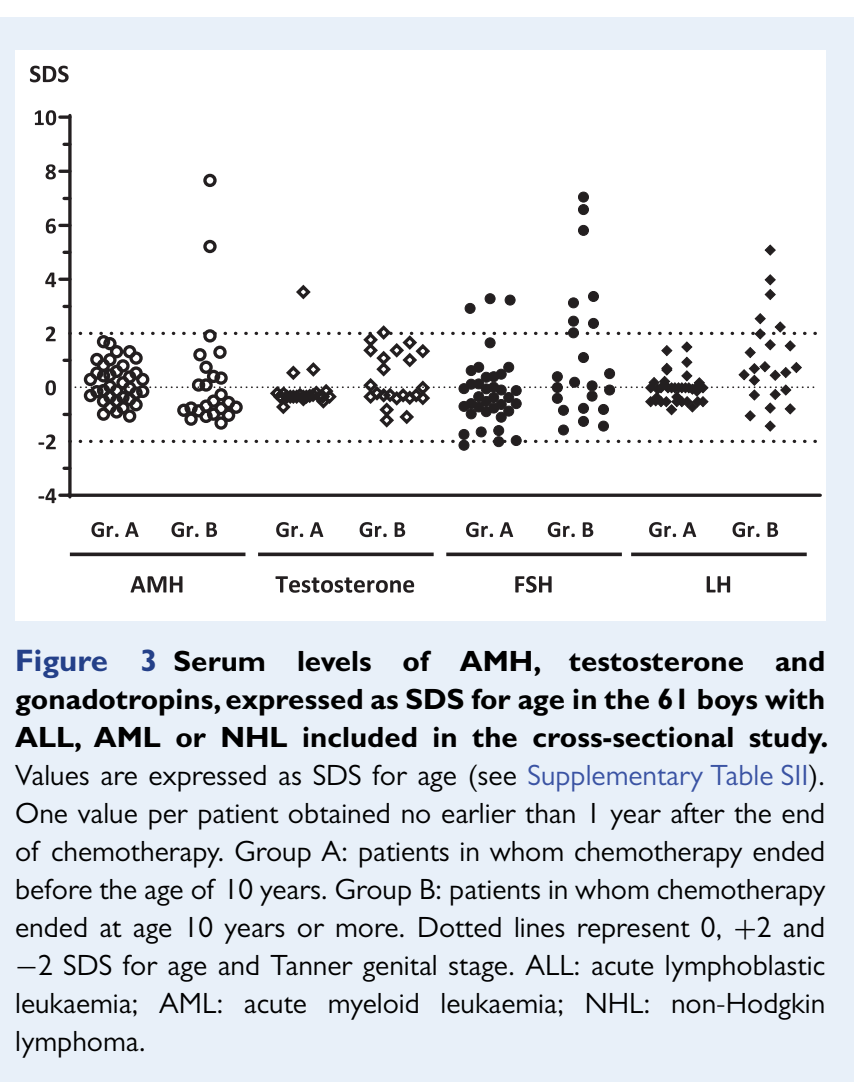

the malignant disease and I patient with trisomy 2 I (Grinspon et al., $20 \mathrm{II}$ ). Therefore, 97 paediatric male patients, i.e. $65.5 \%$ of those in our database, were analysed: 83 with ALL, 5 with AML and 9 with $\mathrm{NHL}$. As expected, common B-cell ALL was the most prevalent form. Patients classified with $\mathrm{SR}$ and IR, and thus receiving a similar treatment protocol, were the vast majority: they represented $90 \%$ of patients with ALL and $77 \%$ of all patients in the study (Table I). Regarding hospital origin, 76 patients were recruited at Ricardo Gutiérrez Children's Hospital (65 ALL, 2 AML and $9 \mathrm{NHL}$ ) and 21 at Pedro de Elizalde Children's Hospital ( 8 ALL, 3 AML).

As expected, patients with ALL and AML were slightly younger at diagnosis and at end of chemotherapy than those with $\mathrm{NHL}$. Most patients with ALL (61.4\%) or with AML (80\%), whereas only $33.3 \%$ of patients with $\mathrm{NHL}$, were younger than 10 years at the end of treatment (Group A). The age at endocrine assessment for the cross-sectional part of the study was also lower in patients with ALL and AML: $38.0 \%$ and $40.0 \%$ respectively were still younger than 10 years when hormonal studies were performed after at least I year of follow-up after the end of the last chemotherapy phase (Table II). Bone marrow transplantation (BMT) preconditioning, including total body irradiation (12-18 Gy), was performed in six cases of ALL, and radiotherapy (12-24 Gy) was performed in II cases of ALL and 3 of AML (Table III and Supplementary Table II). The cumulative doses of chemotherapy agents are described in Table III: patients with HR ALL and with AML or NHL received 2fold higher cumulative doses of IV methotrexate and I0-fold higher cumulative doses of $\mathrm{C}$-arabinoside, and were the only ones who received ifosfamide and etoposide. Pegasparagase and erwinase were rarely used, and idarubicin and mitoxantrone were used exclusively in patients with AML.

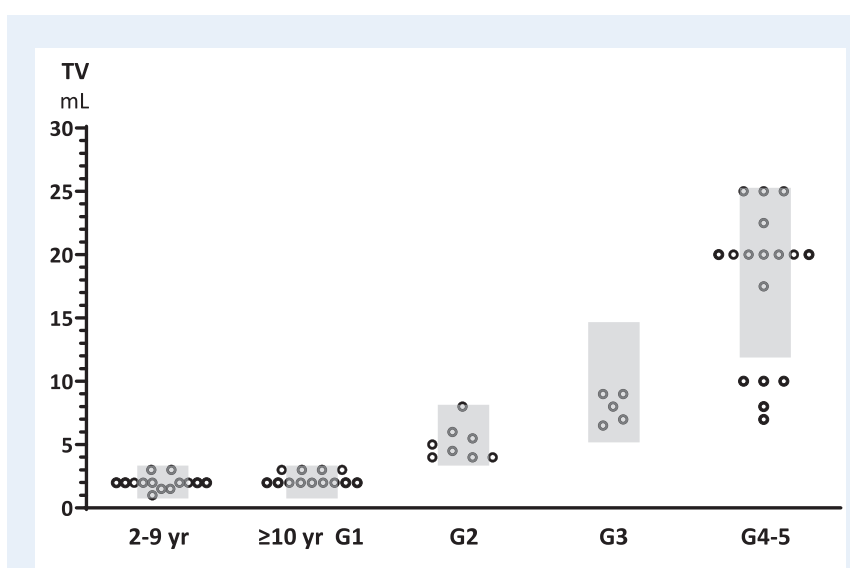

Figure 4 Mean bilateral testicular volume in the 61 boys with ALL, AML or NHL included in the cross-sectional study. Patients are grouped according to age or pubertal Tanner stage at the moment of clinical assessment of testicular volume. One value per patient obtained no earlier than I year after the end of chemotherapy. The grey areas represent normal reference values, according to (Grinspon et al., 20l I). ALL: acute lymphoblastic leukaemia; AML: acute myeloid leukaemia; NHL: non-Hodgkin lymphoma.

Three patients received levothyroxine supplementation due to hypothyroidism, and one patient received treatment with growth hormone.

\section{Cross-sectional study}

There were $6 \mathrm{I}$ patients, with at least I year of follow-up after the end of chemotherapy and one endocrine assessment of testicular function between I and 8 years after the end of chemotherapy, included in the cross-sectional analysis (Table II). Laboratory results from the first assessment available in that period were used. Because serum values of hormones of the gonadal axis vary with age in normal boys during infancy and childhood, values were analysed using SDS for age and pubertal stage groups in the overall evaluation. In the age and pubertal stage subgroup analyses, absolute serum levels and SDS were used.

When the analysis was performed according to the age and Tanner pubertal stage at endocrine assessment, $\mathrm{FSH}$ and/or LH elevation was observed in 13 patients (Fig. 2). Gonadotropin elevation was mild to moderate and was noticed mainly in the older groups (Tanner stages 4-5). Eleven of them had suffered from ALL (three SR and eight IR) and two had suffered from NHL (Burkitt). Only two of these patients with gonadotropin elevation had required total body irradiation and BMT.

Serum levels of $\mathrm{AMH}$, a direct Sertoli cell biomarker, were within the normal levels in all 37 patients treated for ALL, AML or NHL before the age of 10 years (Group A) (Figs 2 and 3). FSH was also normal in the vast majority, and only slightly above the reference range for age in three cases (Fig. 3). Two of them were already $>10$ years old when hormone levels (FSH 3.8 and 8.6 IU/I) were first assessed at least I year after the end of chemotherapy and had testosterone levels ( 12 and I43 ng/dl, respectively) compatible with pubertal onset (Fig. 2). All three had a diagnosis of SR ALL, and none of them had received radiotherapy or BMT preconditioning. 
Group A: End of chemotherapy < 10 years of age
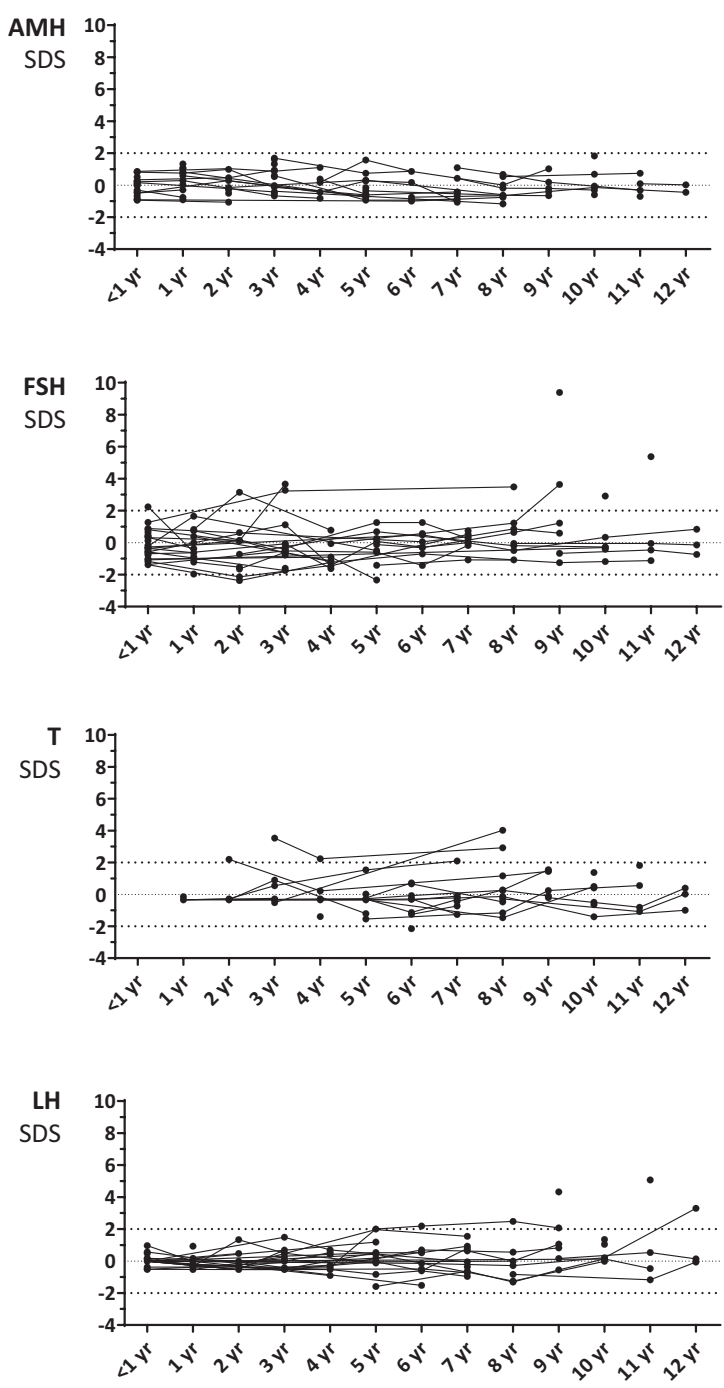

Time after end of chemotherapy (years)
Group B: End of chemotherapy > 10 years of age
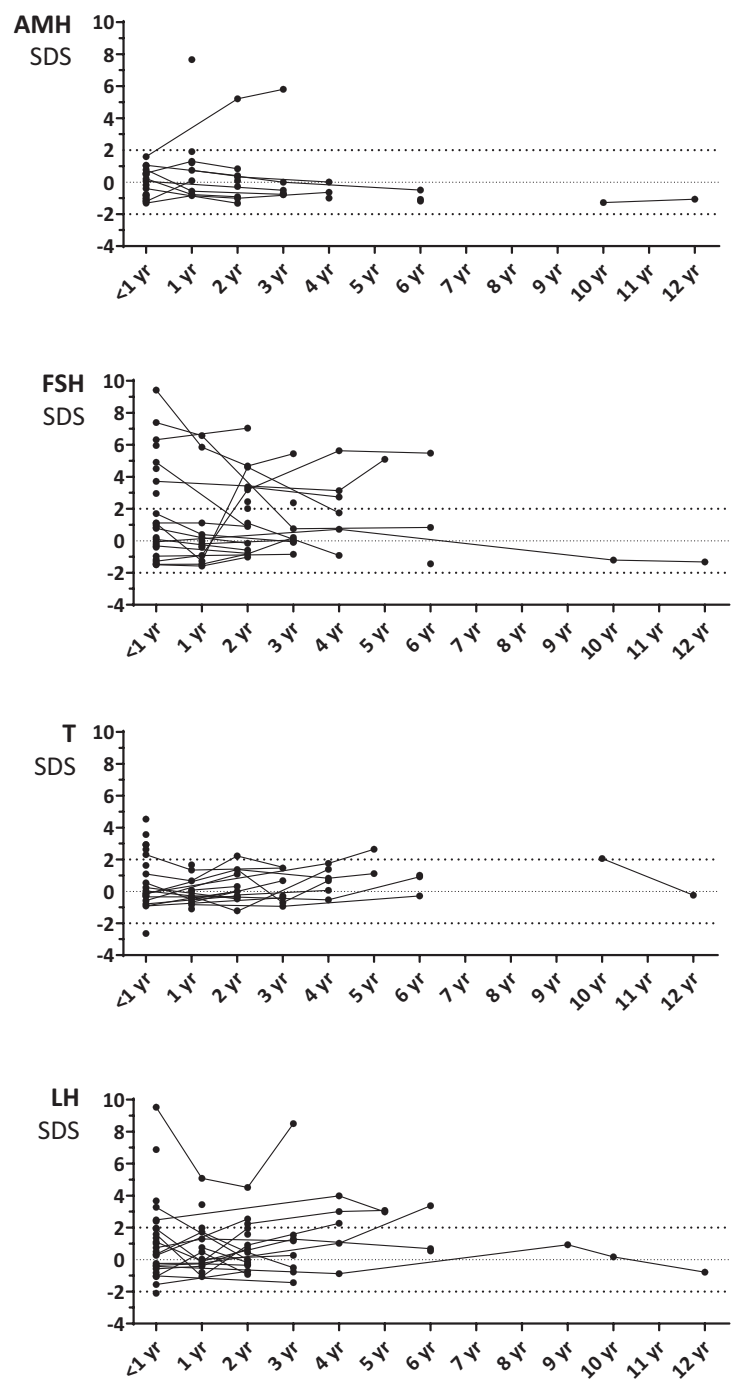

Time after end of chemotherapy (years)

Figure 5 Progression with time after the end of chemotherapy of serum levels of AMH, testosterone and gonadotropins, expressed as SDS for age and Tanner genital stage in the 97 boys with ALL, AML or NHL included in the longitudinal followup study. Values are expressed as SDS for age and Tanner genital score, according to Grinspon et al., 20I I. Group A: patients in whom chemotherapy ended before the age of 10 years. Group B: patients in whom chemotherapy ended at age 10 years or more. ALL: acute lymphoblastic leukaemia; AML: acute myeloid leukaemia; NHL: non-Hodgkin lymphoma.

Serum levels of testosterone and $\mathrm{LH}$, reflecting Leydig cell function, were within the normal levels in all patients treated for ALL, AML or $\mathrm{NHL}$ before the age of 10 years (Group A). However, one patient was first assessed at the age of I I.7 years: since testicular volume was $2 \mathrm{ml}$ bilaterally, he was clinically classified as GI, yet hormonal values were already typical of G2 (LH I.9 IU/I, FSH $0.9 \mathrm{IU} / \mathrm{I}$, testosterone $144 \mathrm{ng} / \mathrm{dl})$. Testicular volume was slightly below normal $(10 \mathrm{ml})$ in only one patient of this group at Tanner stage G4 (Fig. 4), yet he had normal hormone levels.

Given that primary gonadal damage may not elicit gonadotropin elevation during childhood, we performed a subanalysis of those patients of Group A for whom the endocrine function was assessed during puberty, at Tanner stage $\geq \mathrm{G} 3$ : one of six patients had elevated FSH and all had normal LH. Altogether, these results suggest that treatment for childhood cancer before the age of 10 years did not significantly affect testicular endocrine function assessed $>1$ year after the end of treatment in the majority of the cases.

In the 24 patients in whom treatment ended at an age above 10 years (Group B), i.e. more likely to have a reactivated hypothalamicpituitary-gonadal axis, AMH was never found below the reference range but FSH was elevated in eight cases, suggesting the occurrence of a compensated primary Sertoli cell insufficiency. In two patients, one at Tanner stage G3 and one at G4, serum AMH was slightly above 
Group A: End of chemotherapy $<10$ years of age

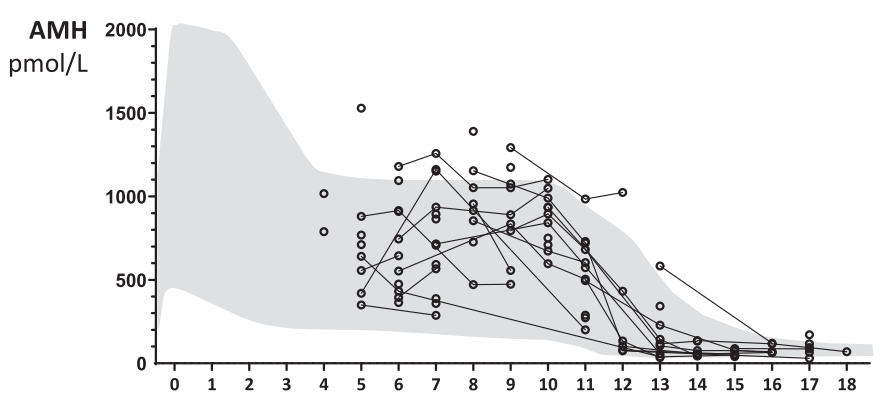

FSH
IU/L

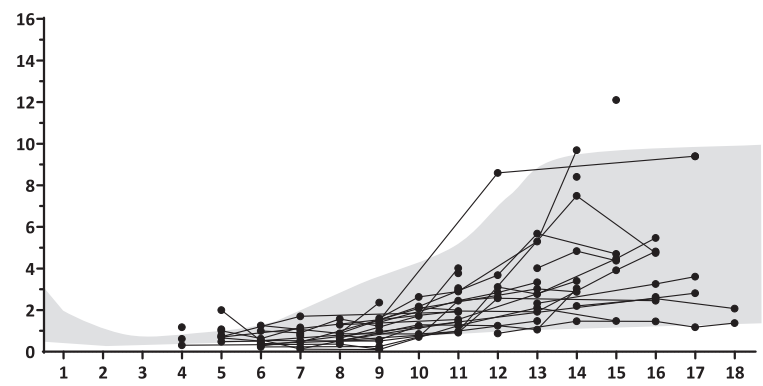

T
$\mathrm{ng} / \mathrm{dL}$

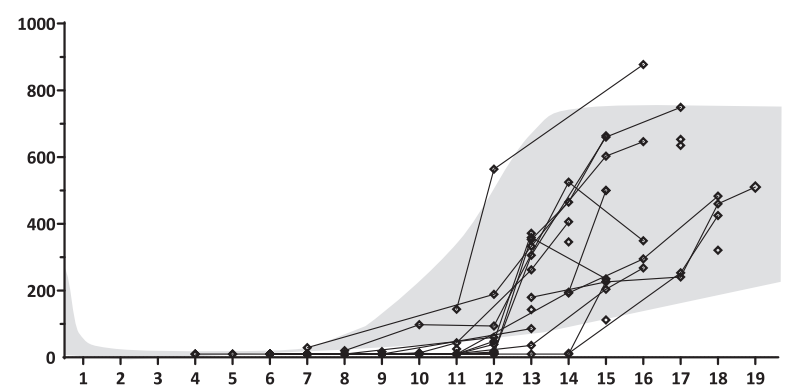

LH

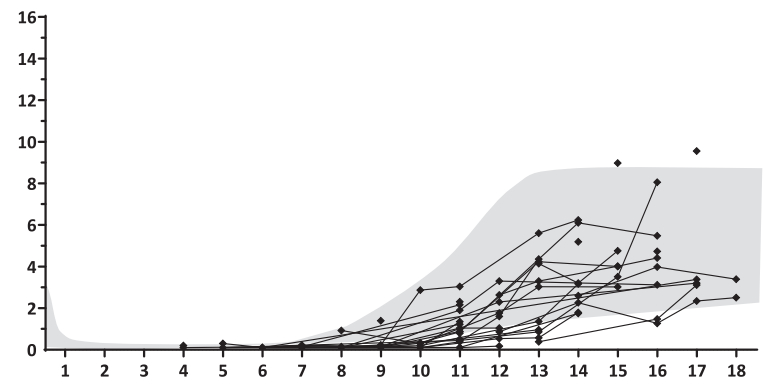

TV

$\mathrm{mL}$

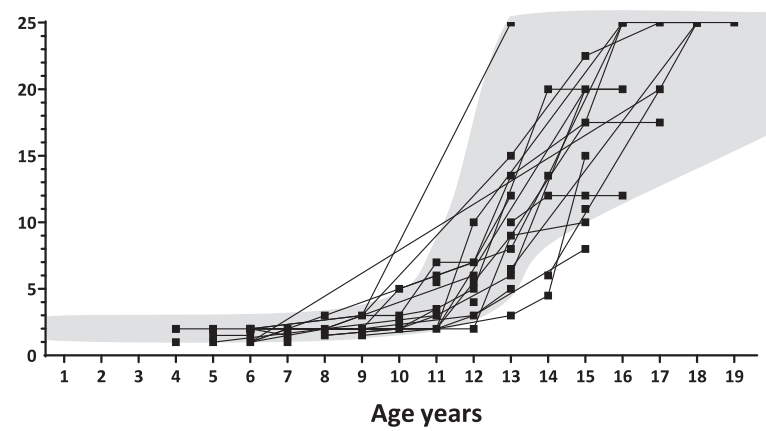

Group B: End of chemotherapy > 10 years of age

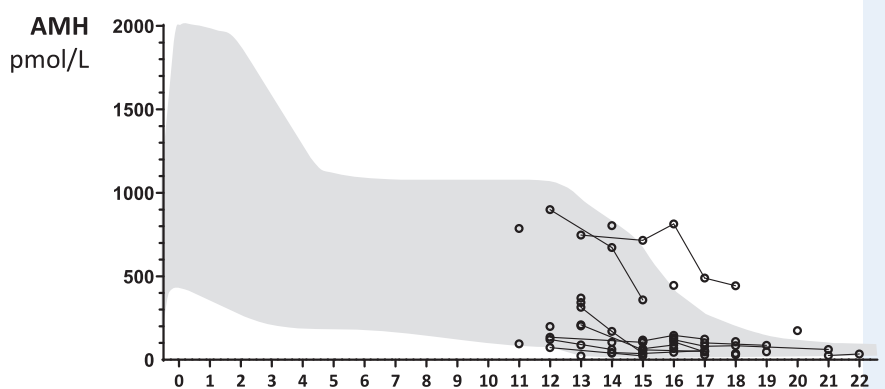

FSH

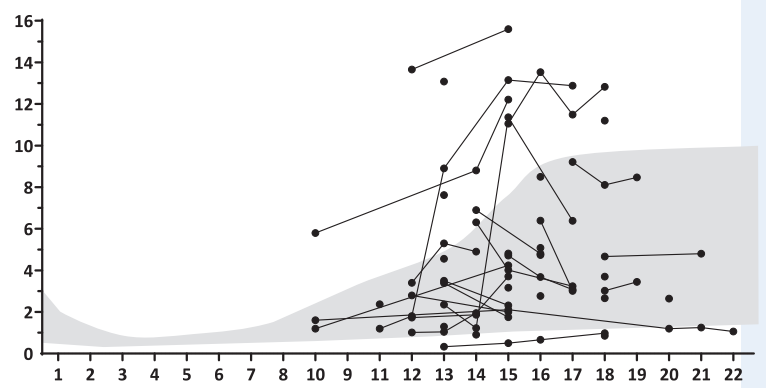

T
$\mathrm{ng} / \mathrm{dL}$

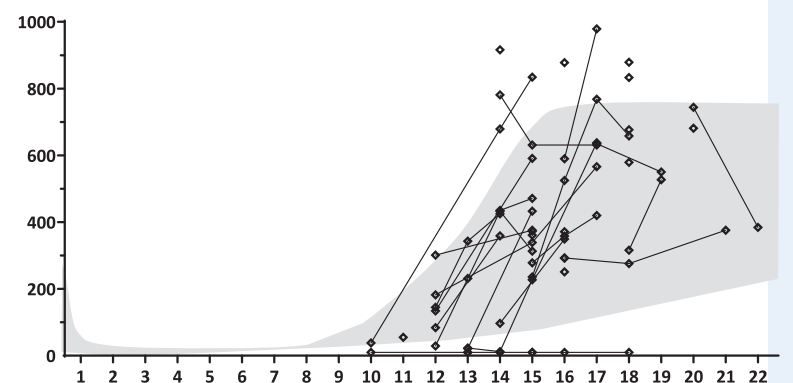

LH
IU/L

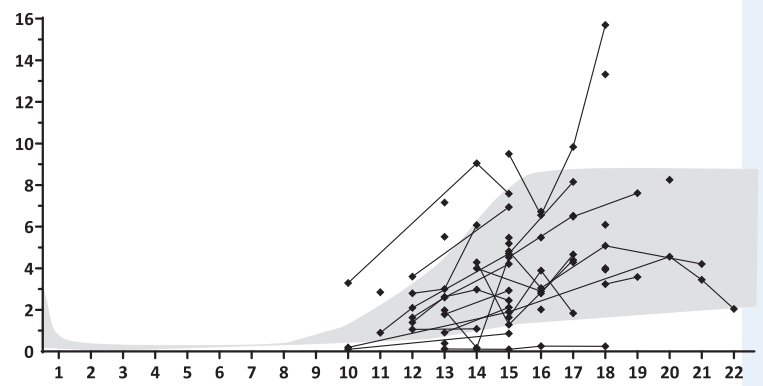

TV

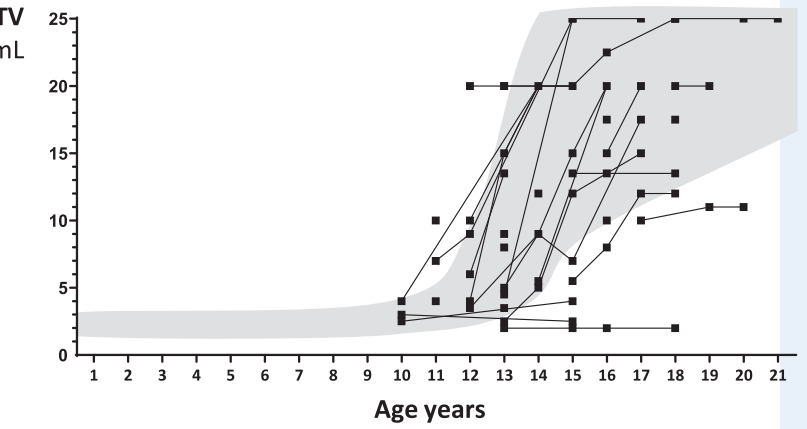

Figure 6 Progression with age of absolute serum levels of AMH, testosterone and gonadotropins in the 97 boys with ALL, AML or NHL included in the longitudinal follow-up study. Group A: patients in whom chemotherapy ended before the age of 10 years. Group B: patients in whom chemotherapy ended at age 10 years or more. The grey areas represent normal reference values, according to Grinspon et al., $201 \mathrm{I}$. ALL: acute lymphoblastic leukaemia; AML: acute myeloid leukaemia; NHL: non-Hodgkin lymphoma. 
Table IV Logistic regressions for chemotherapy agent cumulative doses as independent variables and FSH or $\mathbf{L H}$ as dichotomized variables ( $>+2$ SDS considered as affected; $\leq+2$ SDS considered as normal) in 97 patients.

\begin{tabular}{|c|c|c|c|c|c|c|}
\hline & \multicolumn{3}{|c|}{ FSH (SDS) } & \multicolumn{3}{|c|}{ LH (SDS) } \\
\hline & Odds Ratio & $95 \% \mathrm{Cl}$ & $P$ & Odds Ratio & $95 \% \mathrm{Cl}$ & $P$ \\
\hline Cyclophosphamide $\left(\mathrm{g} / \mathrm{m}^{2}\right)$ & 1.42 & $0.58-3.51$ & 0.45 & 2.68 & $0.55-13.07$ & 0.22 \\
\hline Ifosfamide $\left(\mathrm{g} / \mathrm{m}^{2}\right)$ & 0.73 & $0.35-1.54$ & 0.41 & 0.04 & $0.004-0.57$ & 0.017 \\
\hline Methotrexate IV $\left(\mathrm{g} / \mathrm{m}^{2}\right)$ & 1.09 & $0.98-1.21$ & 0.12 & 1.49 & $0.99-2.25$ & 0.054 \\
\hline Methotrexate oral $\left(\mathrm{g} / \mathrm{m}^{2}\right)$ & 3.25 & $0.78-13.36$ & 0.10 & 9.63 & $0.55-169.17$ & 0.12 \\
\hline 6-Mercaptopurine $\left(\mathrm{g} / \mathrm{m}^{2}\right)$ & 0.92 & $0.83-1.02$ & 0.13 & 0.84 & $0.68-1.03$ & 0.09 \\
\hline 6-Thioguanine $\left(\mathrm{g} / \mathrm{m}^{2}\right)$ & 0.92 & $0.22-3.86$ & 0.91 & 0.001 & $0.0001-0.45$ & 0.026 \\
\hline C-Arabinoside $\left(\mathrm{g} / \mathrm{m}^{2}\right)$ & 1.37 & $0.23-8.11$ & 0.73 & 730.22 & $2.80-190279$ & 0.020 \\
\hline Doxorubicin $\left(\mathrm{g} / \mathrm{m}^{2}\right)$ & 1.00 & $0.97-1.02$ & 0.93 & 1.14 & $1.00-1.30$ & 0.044 \\
\hline Daunorubicin $\left(\mathrm{g} / \mathrm{m}^{2}\right)$ & 1.00 & $0.99-1.02$ & 0.37 & 0.97 & $0.91-1.02$ & 0.19 \\
\hline Vincristine $\left(\mathrm{mg} / \mathrm{m}^{2}\right)$ & 1.10 & $0.93-1.30$ & 0.26 & 1.20 & $0.83-1.75$ & 0.33 \\
\hline L-Asparaginase $\left(\mathrm{g} / \mathrm{m}^{2}\right)$ & 1.00 & $0.99-1.00$ & 0.41 & 1.00 & $0.99-1.00$ & 0.68 \\
\hline Etoposide $\left(\mathrm{mg} / \mathrm{m}^{2}\right)$ & 1.00 & $0.99-1.00$ & 1.00 & 1.01 & $1.00-1.03$ & 0.037 \\
\hline Erwinase $\left(\mathrm{IU} / \mathrm{m}^{2}\right)$ & 1.00 & $0.99-1.00$ & 0.56 & 0.99 & $0.99-1.06$ & 0.99 \\
\hline Pegaspargase $\left(\mathrm{U} / \mathrm{m}^{2}\right)$ & 0.99 & $0.99-1.00$ & 0.18 & 0.48 & $0.99-1.00$ & 0.48 \\
\hline
\end{tabular}

the upper normal range (Fig. 3B); the observation was not considered clinically significant, although a mild degree of Sertoli cell immaturity cannot be ruled out.

Similarly, testosterone levels were within the reference range in all 24 cases, but LH were slightly elevated in five patients receiving treatment after the age of 10 years (Group B), probably indicating a compensated Leydig cell dysfunction (Fig. 3). All these patients were at pubertal stages Tanner G4-5 (Fig. 2). Testicular volume was below normal in five patients at pubertal stages Tanner G4-5 (Fig. 4). Two of them had an elevation of both gonadotropins, one of whom had a relapse leading to BMT.

\section{Longitudinal study}

All 97 patients were included in the longitudinal analysis. Median elapsed time between the end of treatment and the first hormonal assessment was 3.1 years in the whole study sample, ranging from 0.1 to I I.9 years (Table I). Longitudinal data were available for 58 patients who completed treatment before the age of 10 years (Group A) and for 39 who received treatment beyond the age of 10 years (Group B). Serum AMH was never $<2$ SDS for up to 12 years of follow-up (Fig. 5) or below the reference range for age (Fig. 6 ) in patients of Groups A or B, during the whole follow-up. In two cases (Fig. 5), serum AMH was slightly above the upper normal limit for age. Whether this represents a slightly delayed pubertal development could not be ascertained with the available data. Testosterone remained below the reference range in only one pubertal patient.

In Group A, eleven of 58 patients showed at least one serum FSH and/or LH value above the normal range. The elevation was transient in two cases and persistent in nine (I5.5\%): FSH was elevated in eight patients (I3.8\%), suggesting a compensated dysfunction of the tubular component, and LH was elevated in four (6.9\%), which was indicative of compensated Leydig cell dysfunction (Supplementary Table II). Nine patients had ALL (six SR and three IR), two of whom had been exposed to BMT preconditioning (one SR and one IR); these two patients had both gonadotropin levels above the normal range for their respective pubertal stage. Testicular volume remained below the expected value in one patient at age 15 years. In another case, testicular volume was initially low but recovered as pubertal development progressed (Fig. 6).

In Group B, 17 of 39 patients showed at least one elevated gonadotropin value. In 14 cases (35.9\%), the elevation was present in the last available assessment: FSH was elevated in I I (28.2\%) and LH in I0 (25.6\%) (Supplementary Table II). Thirteen patients had ALL (I I IR and $2 \mathrm{HR}$ ), two of whom had been exposed to BMT preconditioning (two IR), and one had NHL. No patient with AML was affected. Testicular volume remained below the expected value in five cases (Fig. 6).

A subanalysis was performed to compare the proportion of gonadotropin elevation between patients of Group A with followup until Tanner stage $\geq G 3(n=23)$ and Group $B(n=39)$. We found no statistically significant difference regarding FSH elevation (Group A, 21.7\%; Group B, 28.2\%; Fisher's exact test, $P=0.40$ ) or $\mathrm{LH}$ elevation (Group A, 17.4\%; Group B, 25.6\%; Fisher's exact test, $P=0.42$ ).

We assessed the association between cumulative doses of chemotherapy agents and the occurrence of gonadal dysfunction. Multiple regression analysis showed that no statistically significant associations were found when patients were categorised into affected Sertoli cell dysfunction (FSH $>+2$ SDS) or not (FSH $\leq+2$ SDS) (Table IV). For Leydig cell dysfunction (i.e. LH $>+2$ SDS), exposure to $\mathrm{C}$-arabinoside appeared as a significant risk factor, whereas exposures to doxorubicin and etoposide marginally increased the odds ratio. Conversely, thioguanine and ifosfamide were associated with a decreased risk of Leydig cell dysfunction (Table IV). The incidence 
of gonadotropin elevation was similar in the three risk groups of ALL: SR, 22.2\%; IR, 33.3\%; and HR, 37.5\%.

\section{Discussion}

In this large study, with prolonged follow-up, we show that oncologic therapy for haematologic malignancies in boys and adolescents did not provoke an overt primary hypogonadism, as revealed by the persistence of normal levels of direct biomarkers of Sertoli cells (AMH) and Leydig cells (testosterone). However, a compensated Sertoli and Leydig cell dysfunction was evidenced by a mild to moderate gonadotropin elevation during pubertal development in up to $35.9 \%$ of the cases. No clinically relevant risk factor, such as severity of the disease or treatment protocol, could be identified in association with the compensated endocrine dysfunction.

Most studies assessing gonadal toxicity of cancer therapy in male adolescents and adults have focused on germ cell toxicity, and identified alkylating agents (busulphan, cyclophosphamide and ifosfamide) in high doses and cis-platinum as high or moderate risk for spermatogenic damage. Our cohort included only patients exposed to the ALL IC-BFM 2002 intercontinental trial protocol adopted by the Argentine Group for the Treatment of Acute Leukaemia (GATLA, Grupo Argentino de Tratamiento de la Leucemia Aguda; Sociedad Argentina de Hematología, 2013). This therapy regimen uses mostly drugs classified as of low risk for spermatogenic toxicity and doses of alkylating agents, like cyclophosphamide and ifosfamide, which are below the expected toxicity risk in the large majority of patients.

The diagnosis of hypogonadism in the male requires the assessment of the different cellular populations of the testis: Leydig, Sertoli and germ cells. The classical definition used in the adult male, equating hypogonadism to low androgen production, is not adequate for male patients of prepubertal age, a period of life when testosterone levels are normally very low or undetectable (Rey et al., 2013, Salonia et al., 2019, Young et al., 2019, Grinspon et al., 2019). Conversely, biomarkers of Sertoli cells, the most active component of the prepubertal testis, are more suitable for the assessment of gonadal function (Josso et al., 20/3). In the present study, we used serum AMH to examine the potential adverse effect of oncologic therapy in prepubertal boys with ALL, AML or NHL. AMH is a widely accepted biomarker of the prepubertal Sertoli cell (Lee et al., 1997, Ankarberg-Lindgren et al., 20 II, Grinspon et al., 20 I2a, van Brakel et al., 2017, Grinspon et al., 2018a) and of granulosa cells of small ovarian follicles, proving to be a useful marker of gonadotoxicity in girls with cancer (Brougham et al., 2012).

No alteration in serum AMH levels was observed in prepubertal patients evaluated at least I year after the end of chemotherapy, radiotherapy or even BMT. In adults, Sertoli cells are expected to be resistant to most chemotherapy agents because they have a mature, stable, nonproliferating phenotype (Dere et al., 2013, Stukenborg et al., 20I8). Conversely, from birth to the initial stages of puberty, Sertoli cells proliferate in response to $\mathrm{FSH}$, with two peaks in infancy and peripuberty (Sharpe et al., 2003), and then mature in response to androgens (O'Shaughnessy et al., 2009, Edelsztein et al., 2016, Edelsztein and Rey, 2019), which could make them more susceptible to chemotherapy or irradiation (Kelnar et al., 2002, Stukenborg et al., 20 I8). Our results indicate that neither of these processes are significantly affected in prepubertal boys treated for haematologic malignancies.

In patients of pubertal age, $\mathrm{AMH}$ and testosterone levels were also within the normal range in almost every case. However, when evaluated beyond Tanner stage G3, i.e. in the context of a reactivated hypothalamic-pituitary-testicular axis, we found an increased prevalence of compensated testicular dysfunction. This was especially revealed by an elevation of serum $\mathrm{FSH}$, an indirect sign of Sertoli cell damage. Concordantly, decreased testicular volume was more frequently observed in patients during the latest pubertal stages (Tanner G4-5). Whether FSH elevation and reduced testicular volume were due to a primary Sertoli cell damage or to germ cell depletion cannot be answered with our data. Sertoli cells proliferate in response to FSH at the very beginning of puberty, then they mature in response to the increase in intratesticular androgen concentration (Grinspon et al., 20 I8b). Sertoli cell maturation is characterised by a cessation of mitotic proliferation, a decrease in AMH production and the development of subcellular structures involved in cell-cell interaction between Sertoli cells, driving the development of the blood-testis barrier, and between Sertoli and germ cells, ultimately responsible for the initiation and stabilisation of adult spermatogenesis. Both pubertal Sertoli and germ cell populations contribute to an increase in inhibin B levels (Andersson et al., 1998, Lahteenmaki et al., 1999, Rohayem et al., 2017), which exert a negative feedback on pituitary FSH secretion. One limitation of our study, due to its retrospective design, is the lack of systematic determination of serum inhibin $B$ in all patients of the cohort. Nevertheless, as mentioned, both Sertoli and germ cells contribute to the pubertal increase in circulating inhibin $B$ and testicular volume. It is therefore difficult to identify the primary damage: whether primary Sertoli cell dysfunction results in secondary depleted spermatogenesis or whether primary germ cell damage impacts on Sertoli cell function and inhibin B secretion. Another limitation of our study is that semen analysis was not performed in those patients with long-term follow-up, which precludes us form concluding on potential fertility impairment. Based on observations made in prepubertal boys exposed to chemotherapy, reduced spermatogonial quantity may be a major contributor to explain the elevation of serum FSH (Masliukaite et al., 20 I6, Poganitsch-Korhonen et al., 20 I7). Finally, although some of our patients received cranial radiotherapy, radiation doses were always below $30 \mathrm{~Gy}$, which do not increase the risk of hypothalamicpituitary-testicular dysfunction (Crowne et al., 20l5, Gebauer et al., 2018).

In this study, our aim was to determine whether the oncologic treatments used in boys and adolescents with ALL, AML or NHL, the set of most frequent paediatric cancers, produce a persistent impairment of the endocrine function of Sertoli and Leydig cells in a period of life characterised by significant developmental changes in the testes. To this end, we included in the cross-sectional analysis patients who had their testicular function assessed at least I year after the end of cancer treatment. We estimated that I year was sufficient for somatic cells to recover after the discontinuation of chemotherapy. Patients susceptible to receive testicular irradiation were not included. Owing to the retrospective design of our study, testicular function was first assessed after variable periods (from I to 8 years) after the end of treatment. We chose to perform the analysis using the first testicular endocrine assessment available after I year had elapsed from the end of chemotherapy, and not assessments after longer-term follow-up, 
to avoid, whenever possible, the confounding effect of developmental changes occurring in puberty. Since Sertoli cell endocrine function was our main focus, we used AMH levels as a direct biomarker. Serum AMH is normally high in prepubertal boys and declines from Tanner stage G2 onwards due to the physiological inhibition of its expression induced by intratesticular testosterone (Rey, 1998, Edelsztein et al., 2018). By selecting the earliest follow-up sample, we reduced the potentially confounding effect of the physiological decline of AMH due to pubertal onset. Also, to minimise this effect, we compared hormone levels in our patients with normative data previously validated for age and Tanner stage (Grinspon et al., 20 I I, Grinspon et al., 20 I2b).

Our series included mainly boys with a diagnosis of ALL, while the $A M L$ and $N H L$ groups were small. The reason for including the latter, together with patients with ALL, was that drug regimens used are similar, and our aim was to assess the effect of treatment rather than the risk of gonadal dysfunction in different childhood cancers. Although big series of patients with only one diagnosis and only one treatment would be the ideal, we believe that ours is one of the most homogeneous series on the subject. Indeed, most series on the effect of oncologic treatment of childhood on testicular function include adult patients with many different types of solid and haematologic cancers, where the treatments are completely different. Intentionally, we did not include in this study patients with other types of cancer.

Leydig cells, while sensitive to radiation therapy when high doses (>24 Gy) need to be used (Jahnukainen et al., 20 I I), seem to be more resistant to chemotherapy. Indeed, the patients of our cohort showed no clinically relevant damage of Leydig cell function, as demonstrated by normal testosterone and $\mathrm{LH}$ levels during pubertal development in the vast majority of cases, with endocrine assessments up to 12 years after the end of oncologic treatment. A compensated Leydig cell dysfunction was observed in a few cases, as reflected by LH elevation whereas a severe hypoandrogenism, requiring testosterone replacement therapy, was seen in only one case with IR ALL, who received standard chemotherapy. Multiple regression identified high doses of c-arabinoside as a potential risk factor, although its effect size needs to be unequivocally proved. In adult males exposed to chemotherapy during childhood, an increased proportion of hypoandrogenism has been observed, especially in association with an increased fat mass and insulin level (Greenfield et al., 2007). The difference between the prevalence of hypoandrogenism observed in adult survivors of childhood cancer and the adolescents in our study might reflect the influence of time or of progressive overweight during adult life. Other studies have identified up to $31 \%$ of Leydig cell failure in adult survivors of childhood cancer (Hudson et al., 2013). The higher proportion of Leydig cell dysfunction may be due to the inclusion of all childhood cancer types, not only haematologic malignancies, some of which require very aggressive chemotherapy or radiotherapy affecting testicular function primarily or secondarily to hypothalamic-pituitary impairment as a consequence of high-dose cranial radiation protocols (Crowne et al., 20I5).

FSH and LH levels were within the normal range in a large majority of boys whose treatment ended before the age of 10 years. Given that gonadotropins may not increase during prepuberty in response to gonadal damage, we performed a subanalysis in those patients in whom endocrine assessments were available during puberty. We found no statistically significant differences in the prevalence of elevated gonadotropins, which could reveal a compensated primary hypogo- nadism, between patients treated before and after 10 years of age. However, our study may be underpowered in this analysis, since only part of the cohort treated before the age of 10 years (Group A) reached advanced puberty during follow-up. In a few cases, the elevation of gonadotropins was temporary. Long-term follow-up might identify a subset of patients with transient gonadotropin elevation with subsequent normalisation by the end of pubertal development.

In conclusion, the regimens used in the treatment of patients with ALL, AML or NHL in the past two decades seem not to provoke an overt damage of testicular somatic components, as revealed by normal levels of AMH and testosterone. However, a mild primary testicular dysfunction may be observed, usually compensated by slightly elevated gonadotropin secretion by the pituitary, which generally does not require hormone replacement therapy.

\section{Supplementary data}

Supplementary data are available at Human Reproduction online.

\section{Acknowledgements}

We are extremely grateful to Dr Oscar Brunetto, head of the Division of Endocrinology at the Pedro de Elizalde Children's Hospital, for his interest and facilitating the establishment of this study.

\section{Authors' roles}

R.P.G., G.B., L.A.A. and R.A.R. conceived the study design; R.P.G., M.A., S.P., G.B., M.S., M.M.B., M.G., P.B., A.K., G.O.E., S.G., M.G.R., I.B., L.A.A. and R.A.R. collected clinical and laboratory data; R.P.G., M.A., S.P., G.B., M.S., A.J.B., L.A.A. and R.A.R. analysed the data; R.P.G., L.A.A. and R.A.R. drafted the manuscript; all authors approved the final version.

\section{Funding}

Consejo Nacional de Investigaciones Científicas y Técnicas (CONICET, PIP I I220130100687); Fondo para la Investigación Científica y Tecnológica (FONCYT, PICT 2016-0993), Argentina.

\section{Conflict of interest}

R.A.R., R.P.G. and P.B. have received honoraria from CONICET (Argentina) for technology services using the AMH ELISA. L.A.A. is part-time employee of CSL Behring Argentina. The other authors have no conflicts of interest to disclose.

\section{References}

Allen CM, Lopes F, Mitchell R, Spears N. How does chemotherapy treatment damage the prepubertal testis? Reproduction 2018. doi: 10.1530/REP-18-0221.

Andersson AM, Müller J, Skakkebæk NE. Different roles of prepubertal and postpubertal germ cells and Sertoli cells in the regulation of serum inhibin B levels. J Clin Endocrinol Metab 1998;83:445 I-4458. 
Ankarberg-Lindgren C, Westphal O, Dahlgren J. Testicular size development and reproductive hormones in boys and adult males with Noonan syndrome: a longitudinal study. Eur J Endocrinol 201 I; 165:137-144.

Arber DA, Orazi A, Hasserjian R, Thiele J, Borowitz MJ, Le Beau MM, Bloomfield CD, Cazzola M, Vardiman JW. The 2016 revision to the World Health Organization classification of myeloid neoplasms and acute leukemia. Blood 20 16; 1 27:2391-2405.

Armstrong GT, Chen Y, Yasui Y, Leisenring W, Gibson TM, Mertens AC, Stovall M, Oeffinger KC, Bhatia S, Krull KR et al. Reduction in late mortality among 5-year survivors of childhood cancer. N Engl J Med 2016;374:833-842.

Bar-Shira Maymon B, Yogev L, Marks A, Hauser R, Botchan A, Yavetz $\mathrm{H}$. Sertoli cell inactivation by cytotoxic damage to the human testis after cancer chemotherapy. Fertil Steril 2004;8 I: 139|-1394.

Bordallo MA, Guimaraes MM, Pessoa CH, Carrico MK, Dimetz T, Gazolla HM, Dobbin J, Castilho IA. Decreased serum inhibin B/FSH ratio as a marker of Sertoli cell function in male survivors after chemotherapy in childhood and adolescence. J Pediatr Endocrinol Metab 2004; 1 7:879-887.

Brämswig JH, Heimes $U$, Heiermann E, Schlegel W, Nieschlag E, Schellong G. The effects of different cumulative doses of chemotherapy on testicular function. Results in 75 patients treated for Hodgkin's disease during childhood or adolescence. Cancer 1990;65:1298-1302.

Brougham MF, Crofton PM, Johnson EJ, Evans N, Anderson RA, Wallace WH. Anti-Müllerian hormone is a marker of gonadotoxicity in pre- and postpubertal girls treated for cancer: a prospective study. J Clin Endocrinol Metab 2012;97:2059-2067.

Crowne E, Gleeson H, Benghiat H, Sanghera P, Toogood A. Effect of cancer treatment on hypothalamic-pituitary function. Lancet Diabetes Endocrinol 2015;3:568-576.

Cuny A, Trivin C, Brailly-Tabard S, Adan L, Zerah M, Sainte-Rose C, Alapetite C, Brugieres L, Habrand JL, Doz F et al. Inhibin B and anti-Müllerian hormone as markers of gonadal function after treatment for medulloblastoma or posterior fossa ependymoma during childhood. J Pediatr 201 I; I58:1016, el01I-el022.

Dere E, Anderson LM, Hwang K, Boekelheide K. Biomarkers of chemotherapy-induced testicular damage. Fertil Steril 2013; 100: I 192-1202.

Edelsztein NY, Grinspon RP, Schteingart HF, Rey RA. Anti-Müllerian hormone as a marker of steroid and gonadotropin action in the testis of children and adolescents with disorders of the gonadal axis. Int J Pediatr Endocrinol 20 16;20 I 6:20.

Edelsztein NY, Racine C, di Clemente N, Schteingart HF, Rey RA. Androgens downregulate anti-Müllerian hormone promoter activity in the Sertoli cell through the androgen receptor and intact SFI sites. Biol Reprod 2018;99:1303-1312.

Edelsztein NY, Rey RA. Importance of the androgen receptor signaling in gene transactivation and transrepression for pubertal maturation of the testis. Cell 2019;8:I-17.

Gebauer J, Higham C, Langer T, Denzer C, Brabant G. Long-term endocrine metabolic consequences of cancer treatment: a systematic review. Endocr Rev 2019;40:71 I-767.

Greenfield DM, Walters SJ, Coleman RE, Hancock BW, Eastell R, Davies HA, Snowden JA, Derogatis L, Shalet SM, Ross RJ. Prevalence and consequences of androgen deficiency in young male cancer survivors in a controlled cross-sectional study. J Clin Endocrinol Metab 2007;92:3476-3482.

Grinspon RP, Bedecarrás P, Ballerini MG, Iñíguez G, Rocha A, Mantovani Rodrigues Resende EA, Brito VN, Milani C, Figueroa Gacitua $\mathrm{V}$, Chiesa $\mathrm{A}$ et al. Early onset of primary hypogonadism revealed by serum anti-Müllerian hormone determination during infancy and childhood in trisomy 21. Int J Androl 201 I;34:e487-e498.

Grinspon RP, Freire AV, Rey RA. Hypogonadism in Pediatric Health: Adult Medicine Concepts Fail. Trends in Endocrinology and Metabolism 2019. doi: 10.1016/j.tem.2019.08.002.

Grinspon RP, Gottlieb S, Bedecarras P, Rey RA. Anti-Müllerian hormone and testicular function in prepubertal boys with cryptorchidism. Front Endocrinol (Lausanne) 2018a;9:|8|-||4.

Grinspon RP, Loreti N, Braslavsky D, Bedecarrás P, Ambao V, Gottlieb S, Bergadá I, Campo SM, Rey RA. Sertoli cell markers in the diagnosis of paediatric male hypogonadism. J Pediatr Endocrinol Metab 2012a;25:3-II.

Grinspon RP, Ropelato MG, Bedecarrás P, Loreti N, Ballerini MG, Gottlieb S, Campo SM, Rey RA. Gonadotrophin secretion pattern in anorchid boys from birth to pubertal age: pathophysiological aspects and diagnostic usefulness. Clin Endocrinol (Oxf) 20I2b;76:698-705.

Grinspon RP, Urrutia M, Rey RA. Male central hypogonadism in paediatrics - the relevance of follicle-stimulating hormone and Sertoli cell markers. Eur Endocrinol 2018b; 14:67-7I.

Heikens J, Behrendt H, Adriaanse R, Berghout A. Irreversible gonadal damage in male survivors of pediatric Hodgkin's disease. Cancer 1996; 78:2020-2024.

Hudson MM, Ness KK, Gurney JG, Mulrooney DA, Chemaitilly W, Krull KR, Green DM, Armstrong GT, Nottage KA, Jones KE et al. Clinical ascertainment of health outcomes among adults treated for childhood cancer. JAMA 2013;309:237I-238I.

Hunger SP, Mullighan CG. Acute lymphoblastic leukemia in children. N Engl J Med 20I5;373:154I-I552.

Jahnukainen K, Ehmcke J, Hou M, Schlatt S. Testicular function and fertility preservation in male cancer patients. Best Pract Res Clin Endocrinol Metab 201 I;25:287-302.

Jahnukainen K, Stukenborg JB. Clinical review: present and future prospects of male fertility preservation for children and adolescents. J Clin Endocrinol Metab 2012;97:434I-435I.

Josso N, Rey RA, Picard JY. Anti-Müllerian hormone: a valuable addition to the toolbox of the pediatric endocrinologist. Int J Endocrinol 2013;2013:674105.

Kelnar CJ, McKinnell C, Walker M, Morris KD, Wallace WH, Saunders PT, Fraser HM, Sharpe RM. Testicular changes during infantile 'quiescence' in the marmoset and their gonadotrophin dependence: a model for investigating susceptibility of the prepubertal human testis to cancer therapy? Hum Reprod 2002; I 7: 1367-1378.

Kenney LB, Cohen LE, Shnorhavorian M, Metzger ML, Lockart B, Hijiya N, Duffey-Lind E, Constine L, Green D, Meacham L. Male reproductive health after childhood, adolescent, and young adult cancers: a report from the Children's Oncology Group. J Clin Oncol 2012;30:3408-3416.

Kesari KK, Agarwal A, Henkel R. Radiations and male fertility. Reprod Biol Endocrinol 2018; I6: I I8.

Lahteenmaki PM, Arola M, Suominen J, Salmi TT, Andersson AM, Toppari J. Male reproductive health after childhood cancer. Acta Paediatr 2008;97:935-942. 
Lahteenmaki PM, Toppari J, Ruokonen A, Laitinen P, Salmi TT. Low serum inhibin $B$ concentrations in male survivors of childhood malignancy. Eur J Cancer 1999;35:612-619.

Laporte S, Couto-Silva AC, Trabado S, Lemaire P, Brailly-Tabard S, Esperou H, Michon J, Baruchel A, Fischer A, Trivin C et al. Inhibin $B$ and anti-Müllerian hormone as markers of gonadal function after hematopoietic cell transplantation during childhood. BMC Pediatr 20I I; I I:20.

Lee MM, Donahoe PK, Silverman BL, Hasegawa T, Hasegawa Y, Gustafson ML, Chang YC, MacLaughlin DT. Measurements of serum Müllerian inhibiting substance in the evaluation of children with nonpalpable gonads. N Engl J Med 1997;336: |480-| 486.

Lim JY, Bhatia S, Robison LL, Yang JJ. Genomics of racial and ethnic disparities in childhood acute lymphoblastic leukemia. Cancer 20|4; 1 20:955-962.

Marshall WA, Tanner JM. Variations in the pattern of pubertal changes in boys. Arch Dis Child 1970;45: 13-23.

Masliukaite I, Hagen JM, Jahnukainen K, Stukenborg JB, Repping S, van der Veen F, van Wely M, van Pelt AM. Establishing reference values for age-related spermatogonial quantity in prepubertal human testes: a systematic review and meta-analysis. Fertil Steril 2016; 106: 1652-1657 el652.

O'Shaughnessy PJ, Morris ID, Huhtaniemi I, Baker PJ, Abel MH. Role of androgen and gonadotrophins in the development and function of the Sertoli cells and Leydig cells: data from mutant and genetically modified mice. Mol Cell Endocrinol 2009;306:2-8.

Poganitsch-Korhonen M, Masliukaite I, Nurmio M, Lahteenmaki P, van Wely M, van Pelt AM, Jahnukainen K, Stukenborg JB. Decreased spermatogonial quantity in prepubertal boys with leukaemia treated with alkylating agents. Leukemia 2017.

Rey R. Endocrine, paracrine and cellular regulation of postnatal antiMüllerian hormone secretion by Sertoli cells. Trends Endocrinol Metab 1998;9:27I-276.

Rey RA. Mini-puberty and true puberty: differences in testicular function. Ann Endocrinol (Paris) 2014;75:58-63.

Rey RA, Grinspon RP, Gottlieb S, Pasqualini T, Knoblovits P, Aszpis S, Pacenza N, Stewart Usher J, Bergadá I, Campo SM. Male hypogonadism: an extended classification based on a developmental, endocrine physiology-based approach. Andrology 20। 3; I:3-16.

Rohayem J, Hauffa BP, Zacharin M, Kliesch S, Zitzmann M. German Adolescent Hypogonadotropic Hypogonadism Study G. Testicular growth and spermatogenesis: new goals for pubertal hormone replacement in boys with hypogonadotropic hypogonadism? -a mul- ticentre prospective study of hCG/rFSH treatment outcomes during adolescence. Clin Endocrinol (Oxf) 2017;86:75-87.

Romerius P, Stahl O, Moell C, Relander T, Cavallin-Stahl E, Wiebe T, Giwercman YL, Giwercman A. High risk of azoospermia in men treated for childhood cancer. Int J Androl 201 1;34:69-76.

Salonia A, Rastrelli G, Hackett G, Seminara S, Huhtanemi I, Rey RA, Hellstrom WJ, Palmert MR, Corona G, Dohle GR et al. Paediatric and adult-onset male hypogonadism. Nat Rev Dis Primers 2019;30:38.

Sharpe RM, McKinnell C, Kivlin C, Fisher JS. Proliferation and functional maturation of Sertoli cells, and their relevance to disorders of testis function in adulthood. Reproduction 2003; I 25:769-784.

Sklar CA, Antal Z, Chemaitilly W, Cohen LE, Follin C, Meacham LR, Murad MH. Hypothalamic-pituitary and growth disorders in survivors of childhood cancer: an Endocrine Society Clinical Practice Guideline. J Clin Endocrinol Metab 2018;103: 2761-2784.

Sociedad Argentina de Hematología. In: Stemmelin G, Palmer S (eds). Guías de Diagnóstico y Tratamiento. Buenos Aires, Argentina: Sociedad Argentina de Hematología, 2013, www.sah.org.ar

Stary J, Zimmermann M, Campbell M, Castillo L, Dibar E, Donska S, Gonzalez A, Izraeli S, Janic D, Jazbec J et al. Intensive chemotherapy for childhood acute lymphoblastic leukemia: results of the randomized intercontinental trial ALL IC-BFM 2002. J Clin Oncol 2014;32:174-184.

Stukenborg JB, Jahnukainen K, Hutka M, Mitchell RT. Cancer treatment in childhood and testicular function: the importance of the somatic environment. Endocr Connect 20 18;7:R69-R87.

Tomova A, Deepinder F, Robeva R, Lalabonova H, Kumanov P, Agarwal A. Growth and development of male external genitalia: a crosssectional study of 6200 males aged 0 to 19 years. Arch Pediatr Adolesc Med 2010; 164: II52-1157.

van Beek RD, Smit M, van den Heuvel-Eibrink MM, de Jong FH, Hakvoort-Cammel FG, van den Bos C, van den Berg $H$, Weber RF, Pieters R, de Muinck Keizer-Schrama SM. Inhibin B is superior to $\mathrm{FSH}$ as a serum marker for spermatogenesis in men treated for Hodgkin's lymphoma with chemotherapy during childhood. Hum Reprod 2007;22:3215-3222.

van Brakel J, de Muinck Keizer-Schrama S, Hazebroek FWJ, Dohle GR, de Jong $\mathrm{FH}$. INSL3 and AMH in patients with previously congenital or acquired undescended testes. J Pediatr Surg 20|7;52:|327-|33।.

Young J, Xu C, Papadakis GE, Acierno JS, Maione L, Hietamaki J, Raivio T, Pitteloud N. Clinical management of congenital hypogonadotropic hypogonadism. Endocr Rev 2019;40:669-710. 


\section{SUPPLEMENTARY DATA}

\section{Diagnosis}

Day 8

Day 15

\begin{tabular}{c|c|}
\hline Age $1-5.9$ years & $\begin{array}{c}\text { Age }<1 \text { or } \geq 6 \text { years } \\
\text { and } \text { WBC }<20.000 \\
\text { and } \text { Blasts }<1000\end{array}$ \\
WBC $\geq 20.000$ \\
Blasts $<1000$
\end{tabular}

$t(9,22)$

or $\mathrm{t}(4,11)$

or Blasts $\geq 1.000$

Day 33
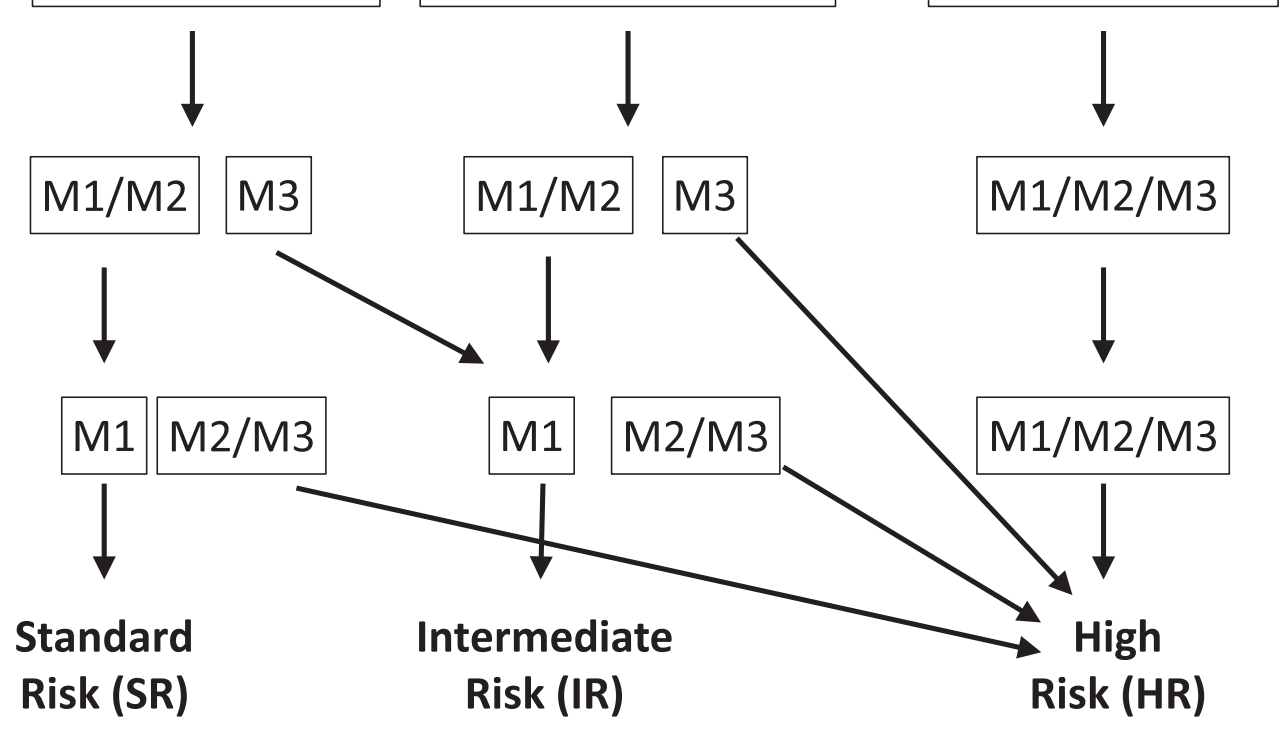

M1: $<5 \%$ Bone Marrow Blasts

M2: 5-25\% Bone Marrow Blasts

M3: > 25\% Bone Marrow Blasts

Supplementary Figure SI Risk stratification and treatment assigned for patients with acute lymphoblastic leukaemia (ALL) according to the ALL IC-BFM 2002 intercontinental trial. Standard risk (SR) definition required the fulfilment of all the following criteria: prednisone good response $\left(<1 \times 10^{9} / /\right.$ blasts in peripheral blood on day 8 after 7 days of prednisone and one dose of intrathecal methotrexate on day I), age I-6 years, initial WBC $<20 \times 10^{9} / \mathrm{I}$, and $\mathrm{MI}$ ( $<5 \%$ blasts) or M2 (5-25\% blasts) marrow on day I5, and MI marrow on day 33 . Intermediate risk (IR) was defined as prednisone-good response, age $<\mathrm{I}$ year or $\geq 6$ years, and/or WBC $\geq 20 \times 10^{9} / \mathrm{I}$ and $\mathrm{MI}$ or M2 marrow on day I5 and MI marrow on day 33 , or SR criteria but $M 3$ ( $\geq 25 \%$ blasts) marrow on day 15 and $M I$ marrow on day 33 . High risk (HR) definition required at least one of the following criteria: prednisone poor response $\left(\geq 1 \times 10^{9} / \mathrm{I}\right.$ blasts in peripheral blood on day 8 after 7 days of prednisone and one dose of intrathecal methotrexate on day I), IR and M3 marrow on day I5, M2 or M3 marrow on day 33, t(9;22) (BCR-ABL), or t(4;II) (MLL-AF4). WBC, white blood cells. 


\section{SUPPLEMENTARY DATA}

Supplementary Table SI Serum gonadotropins, testosterone and AMH levels in 306 healthy males.

\begin{tabular}{|c|c|c|c|c|c|c|}
\hline Age group & & $\mathbf{n}$ & $\begin{array}{c}\text { AMH (pmol/l) } \\
\text { Mean (SD) }\end{array}$ & $\begin{array}{l}\text { FSH (IU/I) } \\
\text { Mean (SD) }\end{array}$ & $\begin{array}{c}\text { T (ng/dl) } \\
\text { Mean (SD) }\end{array}$ & $\begin{array}{c}\text { LH (IU/I) } \\
\text { Mean (SD) }\end{array}$ \\
\hline $2.0-8.9 \mathrm{yr}$ & & 95 & $782(46 I)$ & $0.84(0.52)$ & $10(0)$ & $0.10(0.02)$ \\
\hline \multirow[t]{5}{*}{$9-18$ yr } & GI & 34 & $74 \mid$ (327) & $1.64(0.65)$ & $21.8(34.6)$ & $0.57(0.89)$ \\
\hline & G2 & 34 & $419(301)$ & $2.38(0.92)$ & $57.5(164.5)$ & $1.10(0.88)$ \\
\hline & G3 & 42 & $121(1 \mid 4)$ & $3.29(1.64)$ & $223.1(154.2)$ & $2.37(1.26)$ \\
\hline & G4 & 41 & $75(40)$ & $3.80(1.68)$ & $416.3(154.2)$ & $3.11(1.40)$ \\
\hline & G5 & 60 & $92(50)$ & $3.05(1.73)$ & $426.0(158.9)$ & $3.25(1.52)$ \\
\hline
\end{tabular}

Data from: Grinspon RP, Bedecarrás P, Ballerini MG, Iñíguez G, Rocha A, Mantovani Rodrigues Resende EA, Brito VN, Milani C, Figueroa Gacitua V, Chiesa $A$ et al. Early onset of primary hypogonadism revealed by serum anti-Müllerian hormone determination during infancy and childhood in trisomy 21. Int J Androl 201 I;34: e487-e498.

To obtain serum testosterone in $\mathrm{nmol} / \mathrm{l}$, multiply by 0.03467 . To obtain serum AMH in $\mathrm{ng} / \mathrm{ml}$ divide by 7.14 . 


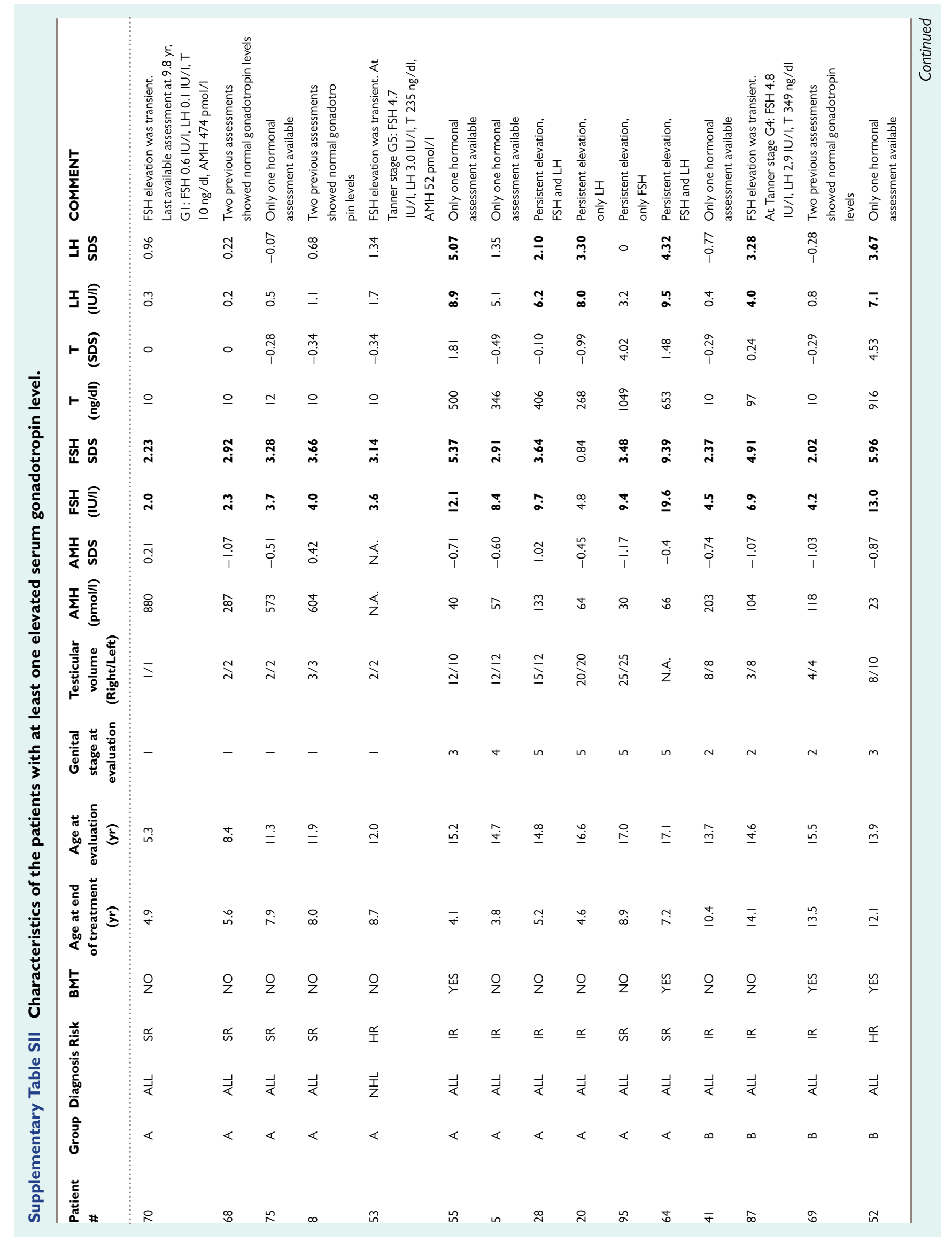




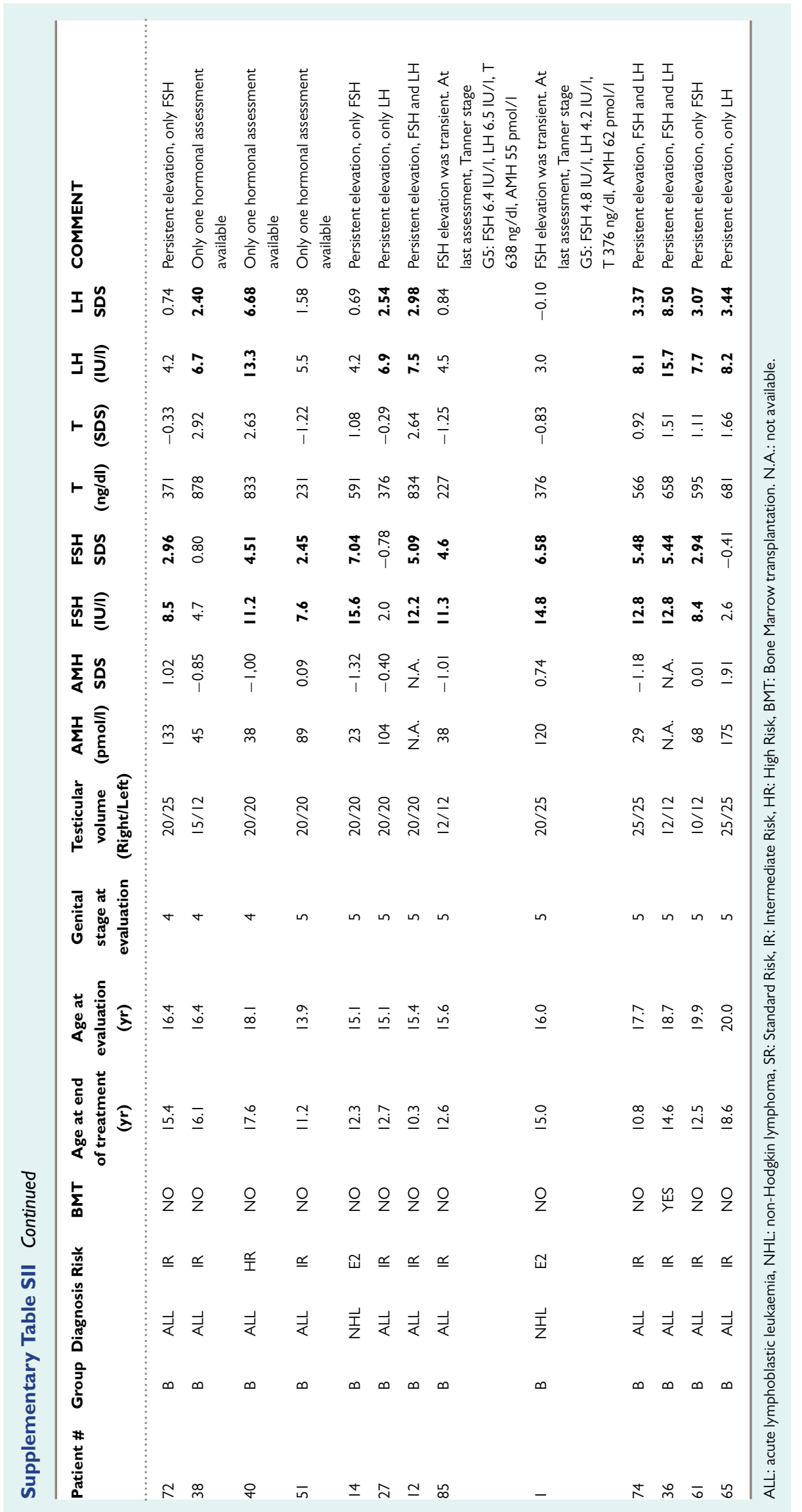

